\title{
Facile Fabrication of Amino-Functionalized MIL- 68(Al) Metal-organic Framework for Effective Adsorption of Arsenate (As(V))
}

\author{
Alireza Rahmani \\ Hamadan University of Medical Sciences \\ Amir Shabanloo \\ Hamadan University of Medical Sciences \\ Solmaz Zabihollahi \\ Hamadan University of Medical Sciences \\ Mehdi Salari ( $\square$ msalari_22@yahoo.com ) \\ Hamadan University of Medical Sciences \\ Mostafa Leili \\ Hamadan University of Medical Sciences \\ Mohammad Khazaei \\ Hamadan University of Medical Sciences \\ Saber Alizadeh \\ Bu-Ali-Sina University \\ Davood Nematollahi \\ Bu-Ali-Sina University
}

\section{Research Article}

Keywords: Amino-functionalized MIL-68(Al), Arsenate adsorption, MOFs, Central composite design, Kinetic model

Posted Date: January 4th, 2022

DOI: https://doi.org/10.21203/rs.3.rs-1206265/v1

License: (c) (i) This work is licensed under a Creative Commons Attribution 4.0 International License.

Read Full License 


\title{
Facile fabrication of amino-functionalized MIL-68(AI) metal-organic framework for effective adsorption of arsenate $(\operatorname{As}(\mathrm{V}))$
}

\author{
Alireza Rahmani ${ }^{\text {a }}$, Amir Shabanloo ${ }^{\text {b*, Solmaz Zabihollahi }}{ }^{\text {b**, }}{ }^{\text {, Mehdi Salari }}{ }^{\text {b*** }}$, Mostafa Leili \\ a, Mohammad Khazaei ${ }^{\text {a }}$,Saber Alizadeh ${ }^{\text {c }}$, Davood Nematollahi ${ }^{\text {c }}$
}
a. Department of Environmental Health Engineering, Faculty of Health and Research Center for Health Sciences, Hamadan University of Medical Sciences, Hamadan, Iran
b. Department of Environmental Health Engineering, Hamadan University of Medical Sciences, Hamadan, Iran
c. Faculty of Chemistry, Bu-Ali-Sina University, Hamadan, Iran

\section{Corresponding authors:}

* Amir Shabanloo, E-mail: shabanlo_a@yahoo.com

** Solmaz Zabihollahi, E-mail: s.zabihollahi@yahoo.com

****Mehdi Salari, msalari_22@yahoo.com 


\section{Abstract}

An amino-functionalized MIL-68(Al) metal-organic framework (amino-MIL-68(Al) MOF) was synthesized by solvothermal method and then characterized by FESEM, XRD, FTIR, EDX-mapping, and BET-BJH techniques. In order to predict arsenate $(\mathrm{As}(\mathrm{V}))$ removal, a robust quadratic model $\left(\mathrm{R}^{2}>0.99, \mathrm{~F}\right.$-value $=2389.17$ and $\mathrm{p}$-value $\left.<0.0001\right)$ was developed by the central composite design (CCD) method and then the genetic algorithm (GA) was utilized to optimize the system response and four independent variables. The results showed that As(V) adsorption on MOF was affected by solution $\mathrm{pH}$, adsorbent dose, $\mathrm{As}(\mathrm{V})$ concentration and reaction time, respectively. Predicted and experimental $\mathrm{As}(\mathrm{V})$ removal efficiencies under optimal conditions were 99.45 and $99.87 \%$, respectively. The fitting of experimental data showed that $\mathrm{As}(\mathrm{V})$ adsorption on MOF is well described by the nonlinear form of the Langmuir isotherm and pseudo-second-order kinetic. At optimum $\mathrm{pH}$ 3, the maximum $\mathrm{As}(\mathrm{V})$ adsorption capacity was $74.29 \mathrm{mg} / \mathrm{g}$. Thermodynamic studies in the temperature range of 25 to $50{ }^{\circ} \mathrm{C}$ showed that $\mathrm{As}(\mathrm{V})$ adsorption is a spontaneous endothermic process. The reusability of MOF in ten adsorption/regeneration cycles was studied and the results showed high reusability of this adsorbent. The highest interventional effect in inhibiting $\mathrm{As}(\mathrm{V})$ adsorption was related to phosphate anion. The results of this study showed that amino-MIL-68(Al) can be used as an effective MOF with a high surface area $\left(>1000 \mathrm{~m}^{2} / \mathrm{g}\right)$ and high reusability for As(V)contaminated water.

Keywords: Amino-functionalized MIL-68(Al), Arsenate adsorption, MOFs, Central composite design, Kinetic model. 


\section{Introduction}

Contamination of water resources with arsenic (As) is a major environmental threat because As, in addition to acute toxicity and high mobility in water sources, has a high accumulation capacity in the food chain and aquatic organisms, so it can cause serious diseases such as skin, kidney, liver and lung cancers in humans [1]. As is recognized by the World Health Organization (WHO) as a priority issue and the guideline for its concentration in drinking water is $10 \mu \mathrm{g} / \mathrm{L}[2,3]$. The toxicity of As depends on the species and its oxidation state. Inorganic species of As in the aquatic environment include arsenite (As (III)) and arsenate (As (V)). In alkaline water sources $(\mathrm{pH}>7.5)$ the predominant species is $\mathrm{As}(\mathrm{III})$, which is 60 times more toxic than As(V) [4]. Organic As species including dimethyl arsenic acid, monomethylarsonic acid and arsenobetaine are about 70 times less toxic than inorganic As species [5]. Various processes have been studied to remove As from contaminated water, including nanofiltration [6], electrochemical techniques [7], chemical precipitation [8], ion exchange [9], and membrane separation [10]. Production of excess sludge, high cost and energy requirement, incomplete removal of pollutants, high chemical requirements and high costs of operation and maintenance are disadvantages of previous methods [11].

Adsorption process is an easy, efficient, cost-effective and environmentally friendly method that is widely used to remove toxic elements from contaminated water [12]. However, the performance of commercial adsorbents such as activated carbon, activated alumina and powdered zeolite for As adsorption has not been satisfactory [13]. Therefore, the main focus of research is on the development of a new group of porous adsorbents that, despite their high reusability, are able to increase the adsorption capacity and adsorption kinetics of As [14].

In this regard, in the last decade, promising and emerging adsorbents called Metal Organic Frameworks (MOFs) have received special attention. MOFs are a unique group of crystalline porous materials whose skeleton consists of coordinated bonds of metal nodes and organic 
linkers [15]. Hence, they are also referred to as porous coordination polymers (PCPs) [16]. Large surface area (1000 to $10000 \mathrm{~m}^{2} / \mathrm{g}$ ), high porosity and high crystallinity are the most important attractive properties of MOFs [14]. Early MOFs could not be used in water due to the instability of the ligand-metal bonds because they decomposed gradually when exposed to moisture. However, metal carboxylate frameworks containing high-valence metal ions are in the group of water-stable MOFs [17]. The MIL family is a group of MOFs composed of trivalent metal cations such as $\mathrm{Al}^{3+}, \mathrm{Cr}^{3+}, \mathrm{V}^{3+}, \mathrm{In}^{3+}$ and $\mathrm{Ga}^{3+}$ and carboxylic acid groups [18]. Among these, $\mathrm{Al}^{3+}$ based MOFs are known as stable adsorbents for adsorption of water pollutants [19].

One of the best-known MOFs in the MIL family is MIL-68(Al), in which the octahedral structures of $\mathrm{AlO}_{4}(\mathrm{OH})_{2}$ are linked together by hydroxyl groups and terephthalate ligands [20]. According to Tehrani et al., the maximum adsorption capacity of Methylene Blue and Rhodamine B dyes on MIL-68(Al) was 1666 and $1111 \mathrm{mg} / \mathrm{g}$, respectively [21]. However, the practical application of most MOFs in industrial conditions is limited due to their poor chemical stability [22]. Research has shown that functionalization of MOFs with amine groups can significantly increase their chemical stability [23]. In addition, modification of MOFs with amine groups increases the number of electron-rich nitrogen sites, which results in more positive charge in the MOF structure [24]. Some MOFs functionalized with amine groups such as Uio-66- $\mathrm{NH}_{2}$ [25], $\mathrm{NH}_{2}-\mathrm{Cu}-\mathrm{MOF}$ [26], amino-functionalized MOF-5 [27] have recently been studied to remove various water contaminants.

However, little attention has been paid to the application of MIL-68(Al) functionalized with amine groups as a water-stable MOF for the removal of heavy metals from contaminated water. Therefore, the aim of this study was to synthesize MIL-68(Al) functionalized with amine group $\left(-\mathrm{NH}_{2}\right)$ (amino-MIL-68(Al)) and use it to remove $\mathrm{As}(\mathrm{V})$ from water. Modeling and optimization of the effect of four independent variables including solution $\mathrm{pH}$, MOF dose, 
reaction time and $\mathrm{As}(\mathrm{V})$ concentration on the adsorption process were performed using response surface methodology-central composite design (RSM-CCD) and genetic algorithm (GA), respectively. Under optimal conditions of adsorption kinetics and isotherms and the effect of interfering anions on the adsorption process was investigated.

\section{Materials and methods}

\subsection{Materials}

All of the reagents including 2-aminoterephthalic acid $\left(\mathrm{NH}_{2}-\mathrm{H}_{2} \mathrm{BDC}\right)$, aluminum chloride hexahydrate $\left(\mathrm{AlCl}_{3} \cdot 6 \mathrm{H}_{2} \mathrm{O}\right), \mathrm{N}, \mathrm{N}$-Dimethylformamide (DMF), and methanol $(\mathrm{MeOH})$ were purchased from Merck Company and utilized without any purification. Disodium hydrogen arsenate $\left(\mathrm{Na}_{2} \mathrm{HAsO}_{4} .7 \mathrm{H}_{2} \mathrm{O}\right)$, hydrochloric acid $(\mathrm{HCl})$, sodium hydroxide $(\mathrm{NaOH})$ was also purchased from Merck Company.

\subsection{Synthesis amino-MIL-68(Al)}

Preparation of MIL-68(Al) by the solvothermal method has been reported in previous studies $[20,28]$. In the present study, 2-aminoterephthalic acid was used as a ligand for the synthesis of amino-MIL-68(Al) instead of terephthalic acid. As briefly, the synthesis was accomplished by dissolving $5.0 \mathrm{~g}(30 \mathrm{mmol})$ 2-aminoterephthalic acid $\left(\mathrm{NH}_{2}-\mathrm{H}_{2} \mathrm{BDC}\right)$ and $4.88 \mathrm{~g}(20 \mathrm{mmol})$ $\mathrm{AlCl}_{3} .6 \mathrm{H}_{2} \mathrm{O}$ in $300 \mathrm{~mL}$ of DMF. The prepared precursor was transferred into a round flask and kept under reflux for $18 \mathrm{~h}$ at $130{ }^{\circ} \mathrm{C}$. After cooling down of mixture, the solid was centrifuged and rinsed three times by DMF for remove the unreacted ligands. Also, the obtained solid was dispersed in $\mathrm{MeOH}$ and rinsed for Three times for remove of the DMF. Finally, the aminoMIL-68(Al) MOF was aged overnight at $100{ }^{\circ} \mathrm{C}$.

\subsection{Characterization of amino-MIL-68(AI)}

The morphology of the synthesized MOF surface was studied with field emission scanning electron microscopy (FESEM) images (FEI-Nova NanoSEM 450). The crystalline structure of the MOF was investigated by X-ray diffraction (XRD) analysis (Ultima IV, Rigaku). 
Functional groups in the MOF structure were also determined by Fourier transform infrared spectroscopy (FTIR, Perkin - Elmer, spectrum 65, Waltham, USA). Energy-dispersive X-ray spectroscopy (EDX) mapping (Bruker XFlash6L10) was used to observe the composition of the elements and their distribution on the synthesized adsorbent surface. Finally, the textural properties of the amino-MIL-68(Al) such as specific surface area and pore size were studied by ADS/DES isotherms of nitrogen obtained at $77 \mathrm{~K}$ (BELsorp mini II, BEL, Japan). The Zeta potential of the prepared MOF at pH 3-11 was measured using a Zeta Sizer (Malvern, England).

\subsection{CCD experimental design}

Experimental design and statistical analysis of data were performed with RSM-CCD. The main advantage of this method is the development of a mathematical model with a small number of experiments that can identify the optimal points of independent variables and evaluate the effect of variables as well as the interaction between them $[29,30]$. In the present study, the effect of four independent variables including solution $\mathrm{pH}(\mathrm{A})$, amino-MIL-68(Al) dose (B), reaction time $(\mathrm{C})$ and $\mathrm{As}(\mathrm{V})$ concentration (D) on the efficiency of $\mathrm{As}(\mathrm{V})$ removal as a system response (Y) was studied by a five-level full CCD. Table 1 shows four independent variables and their five coded levels. Independent variables and their ranges were selected based on experimental data obtained from the pre-test. The designed experiments are also presented in Table 2. Each experimental run was performed with three replications and their mean response was presented as As(V) removal efficiency in Table 2. Statistical analysis of variance (ANOVA) was used to determine the regression coefficients of the model. The graphical relationship between the variables and the system response was also demonstrated using response surface plots. The optimization of independent variables was also performed with the aim of maximizing the efficiency of $\mathrm{As}(\mathrm{V})$ removal by applying the final model equation in the GA tool. Design-Expert 13 and MATLAB R2013a software were used to perform CCD and GA in this study, respectively. 
Table 1. Independent variables and their coded levels

\begin{tabular}{lcccccc}
\hline \multicolumn{1}{c}{ Variable } & Symbols & $-\alpha$ & -1 & 0 & +1 & $+\alpha$ \\
\hline $\mathrm{pH}$ & $\mathrm{A}$ & 3 & 5 & 7 & 9 & 11 \\
Amino-MIL-68(Al) dosage (g/L) & $\mathrm{B}$ & 0.05 & 0.14 & 0.23 & 0.31 & 0.4 \\
Reaction time (min) & $\mathrm{C}$ & 10 & 27.5 & 45 & 62.5 & 80 \\
As(V) concentration (mg/L) & $\mathrm{D}$ & 2.5 & 14.375 & 26.25 & 38.125 & 50 \\
\hline
\end{tabular}

\section{5. $\operatorname{As}(V)$ adsorption experiments}

Adsorption experiments were performed in a batch reactor containing the desired concentrations of $\mathrm{As}(\mathrm{V})$ (D: 2.5-50 mg/L) and amino-MIL-68(Al) MOF (B: 0.05-0.4 g/L). The effect of four independent variables defined in Table 1 was studied on the efficiency of As(V) adsorption. As $(\mathrm{V})$ solutions were prepared synthetically by disodium hydrogen arsenate $\left(\mathrm{Na}_{2} \mathrm{HAsO}_{4} \cdot 7 \mathrm{H}_{2} \mathrm{O}\right)$. In order to completely mix the sample solution containing $\mathrm{As}(\mathrm{V})$ and MOF, a magnetic stirrer with a stirrer speed of $100 \mathrm{rpm}$ was used. $0.1 \mathrm{NaOH}$ and $0.1 \mathrm{HCl}$ solutions were used to adjust the $\mathrm{pH}(\mathrm{A}: 3-11)$ of the sample solution (SensION, HACH). After a specified time $(\mathrm{C}: 10-80 \mathrm{~min})$, the samples were centrifuged for $10 \mathrm{~min}$ at $7000 \mathrm{rpm}$ to separate the MOF from the solution. As(V) concentrations were determined using ICP-MS before and after the adsorption process [31]. As(V) adsorption efficiency (Y, \%) and adsorption capacity $\left(\mathrm{q}_{\mathrm{e}}, \mathrm{mg} / \mathrm{g}\right)$ were calculated by Eqs. 1 and 2 . After optimizing the $\mathrm{As}(\mathrm{V})$ adsorption on the amino-MIL-68(Al), the reusability of the adsorbent was evaluated for ten consecutive reuses. Also, the effect of interfering anions on $\mathrm{As}(\mathrm{V})$ adsorption efficiency in the presence of $\mathrm{Cl}^{-}, \mathrm{SO}_{4}^{2-}, \mathrm{NO}_{3}^{-}$and $\mathrm{PO}_{4}^{3-}$ were evaluated.

$$
\begin{aligned}
& Y(\%)=\frac{\mathrm{C}_{0}-\mathrm{C}_{\mathrm{e}}}{\mathrm{C}_{0}} \times 100 \\
& \mathrm{q}_{\mathrm{e}}=\frac{\left(\mathrm{C}_{0}-\mathrm{C}_{\mathrm{e}}\right) \mathrm{V}}{\mathrm{m}}
\end{aligned}
$$


where $C_{0}(\mathrm{mg} / \mathrm{L})$ and $\mathrm{C}_{\mathrm{e}}(\mathrm{mg} / \mathrm{L})$ represent the initial and final concentrations of $\mathrm{As}(\mathrm{V})$, respectively, $\mathrm{m}(\mathrm{mg})$ is assigned to the mass of amino-MIL-68(Al) MOF, and V (L) is related to the sample solution.

\section{Results and discussion}

\subsection{Characterization of amino-MIL-68(Al)}

Fig. 1 shows the morphology of the amino-MIL-68(Al) surface at different magnifications. As can be seen, the MOF surface consists of cumulative amorphous particles. According to Fig. 1(d), the particle diameters are in the range of 60 to $80 \mathrm{~nm}$. In Wu et al.'s study, a similar structure was reported for aluminum-based MOFs [32]. The XRD spectrum of amino-MIL68(Al) is presented in Fig. 2(a). The Sharp characteristic peaks observed at $2 \theta=5,8.8,9.44$, $12.6,15.25,17.8,19.4,24.9$ and $26.8^{\circ}$ have been reported in previous studies, indicating that the MIL-68(Al) is well synthesized in the MOF structure [32-36].

The functional groups of the synthesized amino-MIL-68(Al) can be seen in Fig. 2(b). The bands appearing at 990, 1257 and 1337 1/cm belong to the $\mathrm{n}(\mathrm{C}-\mathrm{N})$ absorption distinctive of aromatic amines. $\mathrm{N}-\mathrm{H}$ vibration can be seen at bands 1580 and $7761 / \mathrm{cm}$. The symmetrical stretching vibration of $-\mathrm{COOH}$ is also located at bands 1443 and $14961 / \mathrm{cm} . \mathrm{C}-\mathrm{H}$ and $\mathrm{C}=\mathrm{C}$ of the benzene rings can be identified at bands 1123 and 1395 1/cm, respectively. The primary amines $-\mathrm{NH}_{2}$ on organic linkers can be found at band $33861 / \mathrm{cm}$. The band at $34951 / \mathrm{cm}$ belongs to the vibration of $\mathrm{OH}$ group. Finally, the bands at 472, 551, and $6081 / \mathrm{cm}$ belong to the vibrations of the metal center of $\mathrm{Al}-\mathrm{O}$ [37].

Fig. 3 shows the EDX-mapping analysis of the MOF surface. As can be seen, the synthesized amino-MIL-68(Al) consists of a uniform distribution of the elements carbon (61.81 wt. \%), oxygen (31.6 wt. \%), aluminum (4.35 wt. \%), and nitrogen (2.25 wt. \%). Figs. 4(a) and 4(b) show the ADS/DES isotherm of nitrogen and Barrett-Joyner-Halenda $(\mathrm{BJH})$ pore size of MOF, respectively. The shape of the isotherm is similar to type II with $\mathrm{H} 3$ type hysteresis, suggesting 
the presence of mesoporous texture with the micropores [38]. The results also showed that the Brunner-Emmet-Teller (BET) surface area for the synthesized amino-MIL-68(Al) is 1170.9 $\mathrm{m}^{2} / \mathrm{g}$, which is much larger than the surface area reported for MIL-88B(Fe) $\left(214 \mathrm{~m}^{2} / \mathrm{g}\right)$ [39], $\mathrm{NH}_{2}$-MIL-88(Fe) $\left(201 \mathrm{~m}^{2} / \mathrm{g}\right)$ [40] and $\mathrm{NH}_{2}-\mathrm{MIL}-68(\mathrm{In})\left(655 \mathrm{~m}^{2} / \mathrm{g}\right)$ [41]. The mean pore diameter and total pore volume for amino-MIL-68(Al) were also $2.64 \mathrm{~nm}$ and $0.7743 \mathrm{~cm}^{3} / \mathrm{g}$, respectively.

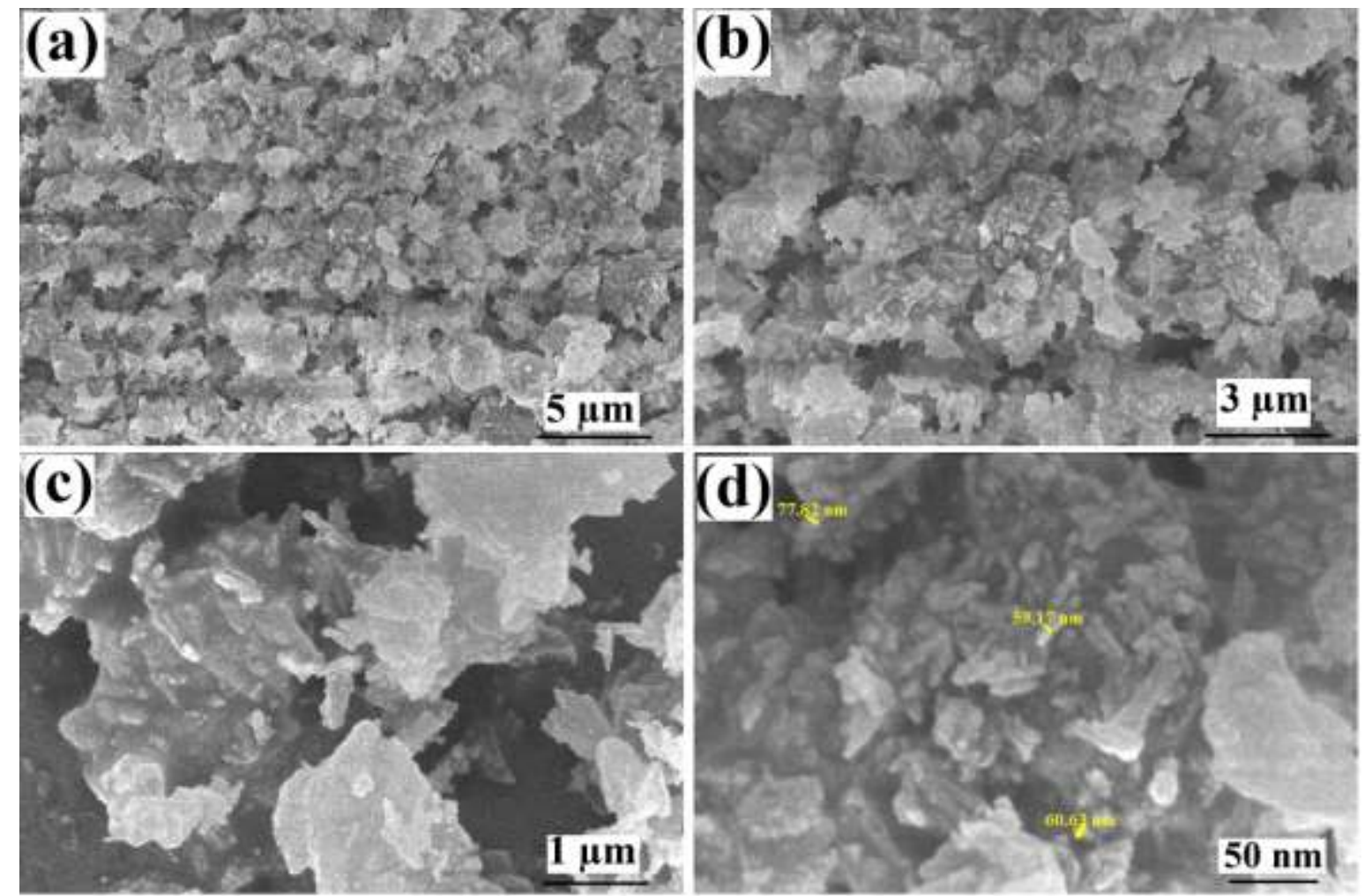

Fig. 1. FESEM images of amino-MIL-68(Al) with different magnifications (a-d). 

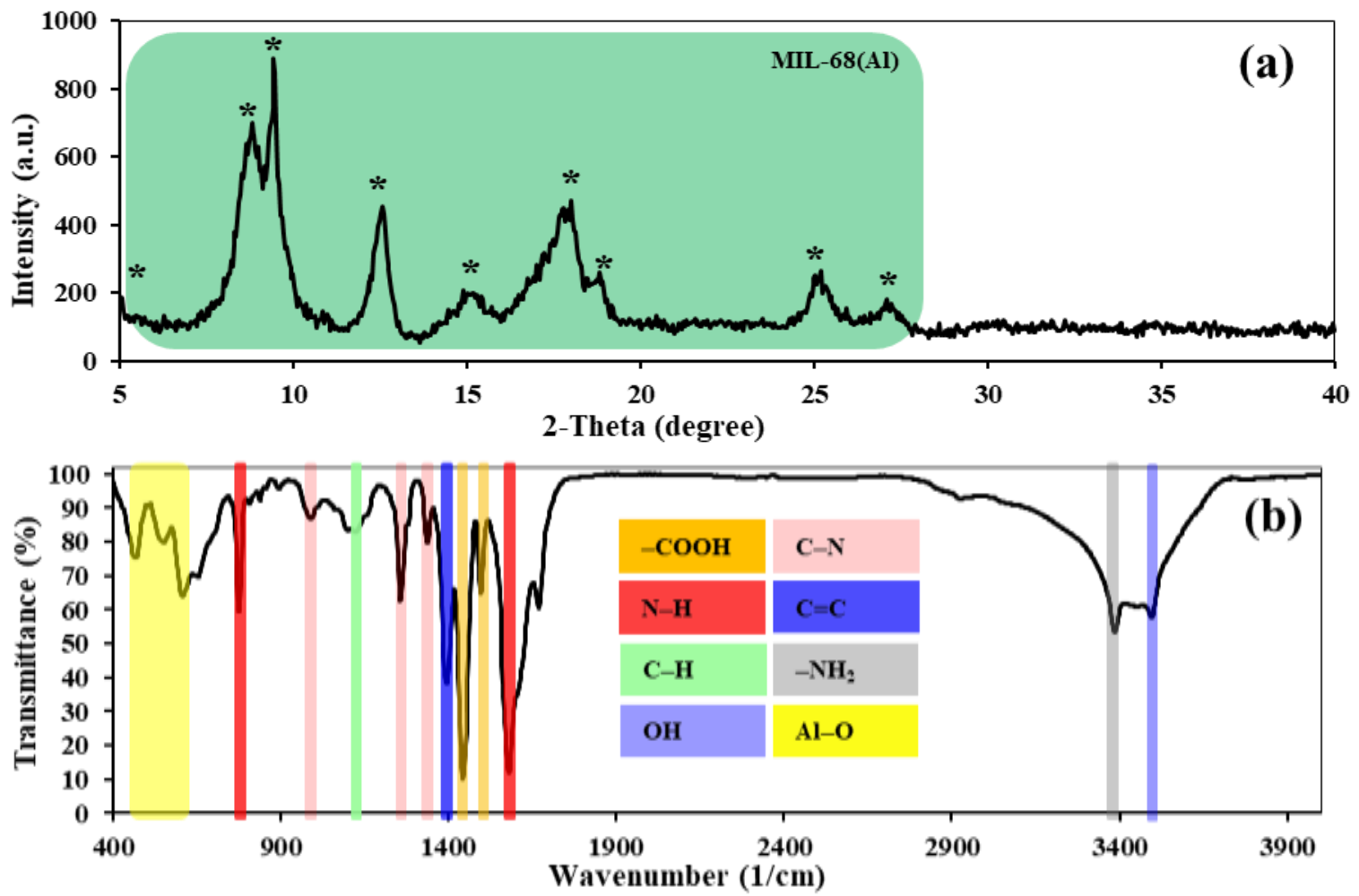

Fig. 2. XRD (a) and FTIR (b) spectra of amino-MIL-68(Al).
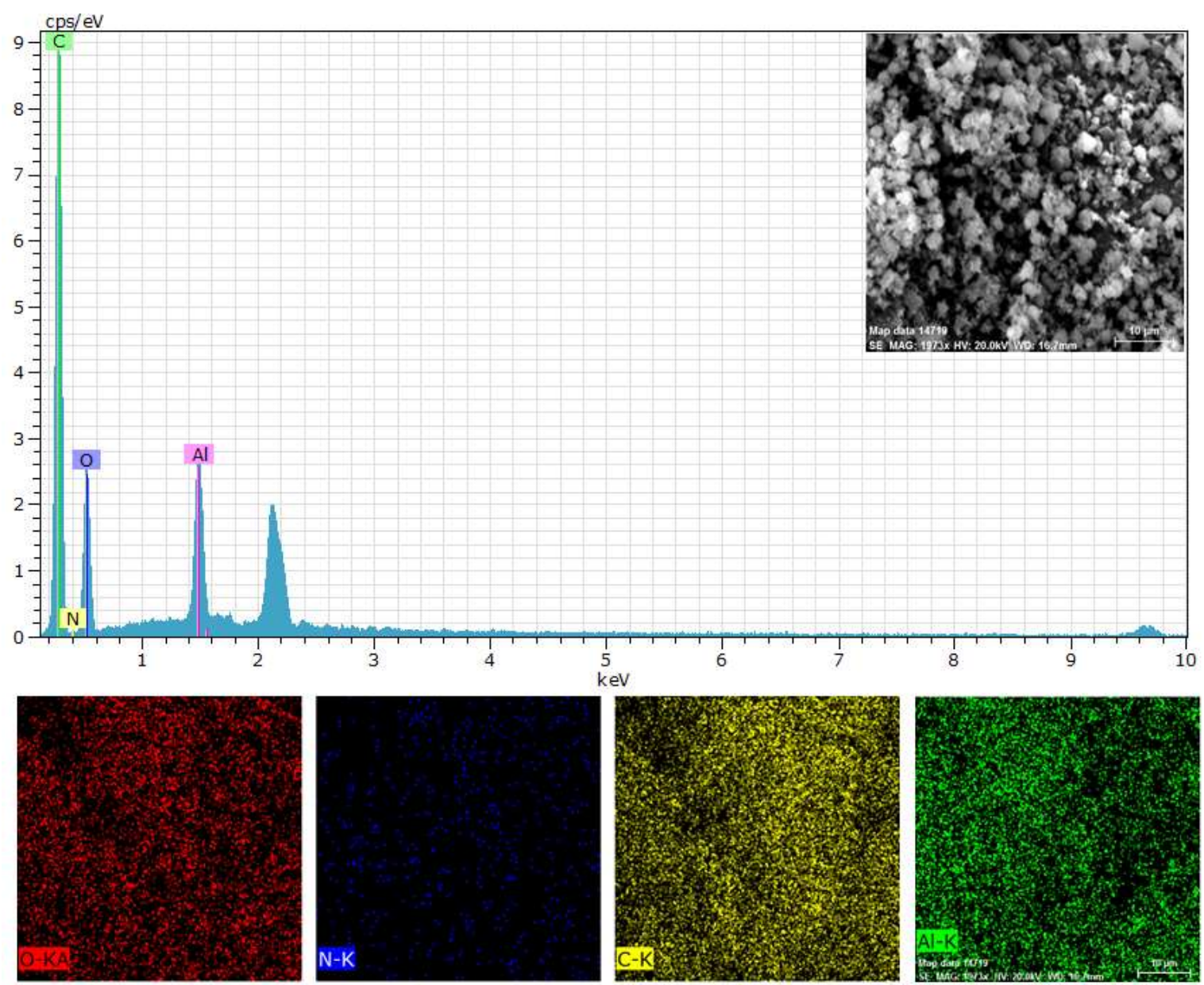

Fig. 3. EDX-mapping analysis of amino-MIL-68(Al). 

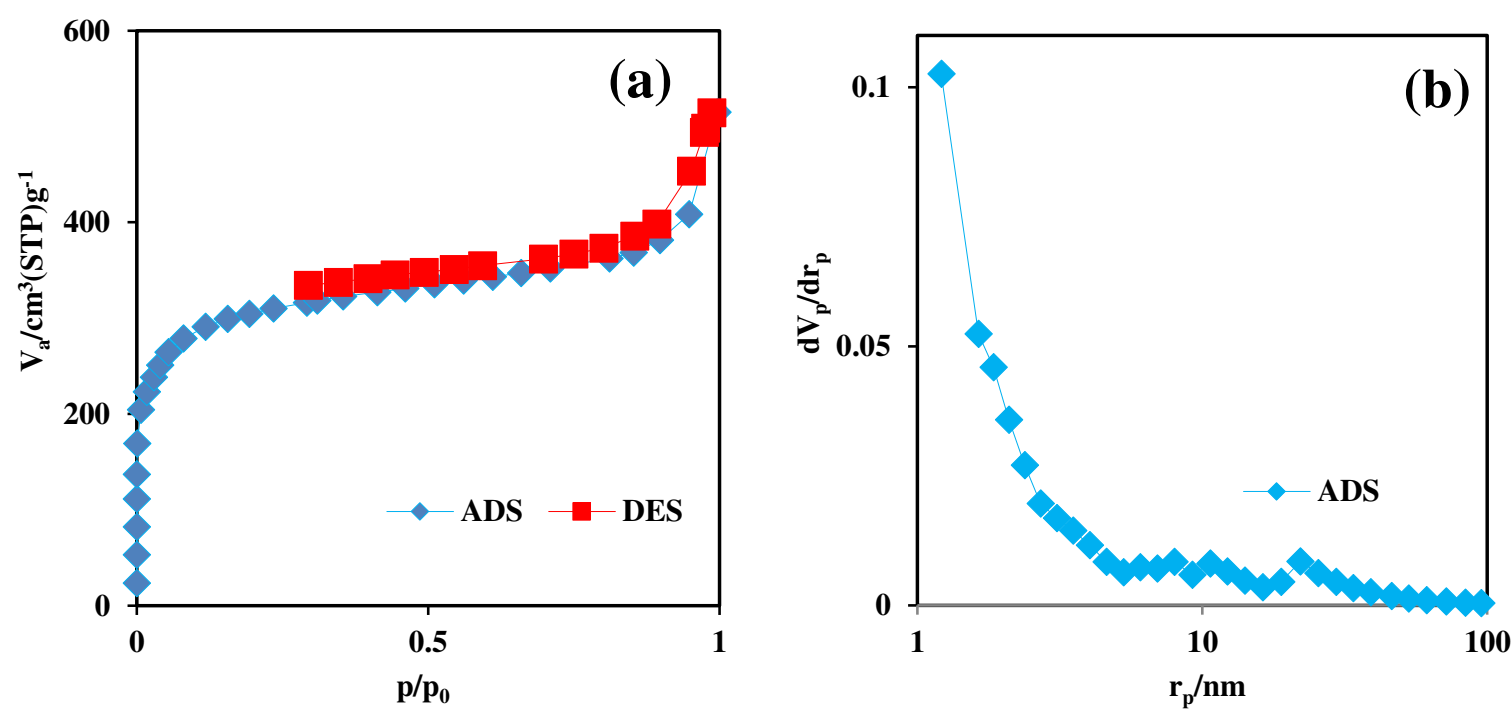

Fig. 4. The ADS/DES isotherm of $\mathrm{N}_{2}$ on amino-MIL-68(Al) (a), BJH pore size of amino-MIL68(Al) (b).

\subsection{Data analysis, process modeling and optimization}

To model As(V) adsorption on amino-MIL-68(Al), experimental design was performed based on CCD method. Table 2 shows the efficiency of $\mathrm{As}(\mathrm{V})$ removal in designed experiments. Data analysis showed that a quadratic model is able to predict system response with $\mathrm{R}^{2}>0.99$. ANOVA results for As(V) adsorption by amino-MIL-68(Al) are shown in Table 3. For the model, F-value and p-value are 2389.17 and $<0.0001$, respectively, which confirms that the developed model is statistically significant. However, Lack of Fit is statistically non-significant because the values of these parameters are 1.23 and 0.4341 , respectively. These results indicate that the data fit well with the developed quadratic model $[42,43]$. The final model equation is presented in Eq. 3. As can be seen, the proposed model is affected by the linear (A, B, C and $\mathrm{D})$, interaction $(\mathrm{AB}, \mathrm{AC}, \mathrm{AD}, \mathrm{BC}, \mathrm{BD}$ and $\mathrm{CD})$ and quadratic $\left(\mathrm{A}^{2}, \mathrm{~B}^{2}, \mathrm{C}^{2}\right.$ and $\left.\mathrm{D}^{2}\right)$ effects of the independent variables. Eq. 4 was used to calculate the percentage effect of each parameter on the system response [30]. The final column in Table 3 shows the percentage of the positive and negative effects of each of the model parameters on the system response. As can be seen, the greatest effects on the system response are related to the linear effects of solution $\mathrm{pH}(\mathrm{A}$ : - 
$41.34 \%)$, amino-MIL-68(Al) dose (B: +28.70), As(V) concentration (D: $-14.29 \%)$ and reaction time (C: $9.98 \%$ ), respectively. In addition, the system response is totally $3.89 \%$ affected by the interaction effects of the independent variables. Among the quadratic effects, the most important parameter affecting the system response is the amino-MIL-68(Al) dose $\left(\mathrm{B}^{2}\right.$ : $-0.178 \%)$.

$Y(\%)=35.49-2.68 A+115.29+0.686 C-0.554 D+3.36 A B-0.034 A C-$

$0.0444 A D+0.333 B C+0.352 B D+0.0017 C D-0.098 A^{2}-108.024 B^{2}-0.0025 C^{2}+$

$0.00217 D^{2}$

$\operatorname{Effect}(\%)=\left[\beta_{i}^{2} / \Sigma\left(\beta_{i}{ }^{2}\right)\right] \times 100$

where $\mathrm{Y}$ indicates the system response or As(V) removal efficiency $(\%)$. A, B, C and D represent the independent variables defined in Table $1 . \beta_{\mathrm{i}}$ is also the regression coefficients of the parameters in the model equation based on coded factors.

GA method was utilized to optimize the process and predict the highest As(V) removal efficiency. For this purpose, the equation of the quadratic model was entered into the software as a fitness function, and the independent variables were adjusted to their high and low values $( \pm \alpha)$ [44]. The software output is shown in Fig. 5. As can be seen, after about 200 generations, the optimal values of the independent variables are predicted. Accordingly, the optimal values for solution $\mathrm{pH}$, amino-MIL-68( $\mathrm{Al})$ dose, reaction time and $\mathrm{As}(\mathrm{V})$ concentration were 3, 0.4 (g/L), $80 \mathrm{~min}$ and $2.5 \mathrm{mg} / \mathrm{L}$, respectively. For these laboratory conditions, the predicted removal efficiency for $\mathrm{As}(\mathrm{V})$ adsorption on amino-MIL-68(Al) was about $99.45 \%$. To evaluate the accuracy of the model, three adsorption experiments were performed under optimal conditions, which showed that the average experimental removal of $\mathrm{As}(\mathrm{V})(99.87 \%)$ is very close to the predicted removal of $\mathrm{As}(\mathrm{V})$.

Table 2. Experimental design with As(V) removal efficiency. 


\begin{tabular}{|c|c|c|c|c|c|}
\hline Run & $\begin{array}{c}\text { Variable } 1 \\
\text { A: pH }\end{array}$ & $\begin{array}{c}\text { Variable } 2 \\
\text { B: MOF dosage } \\
(\mathrm{g} / \mathrm{L})\end{array}$ & $\begin{array}{c}\text { Variable } 3 \\
\text { C: Reaction time } \\
\qquad(\min )\end{array}$ & $\begin{array}{c}\text { Variable } 4 \\
\text { D: As(V) concentration } \\
(\mathrm{mg} / \mathrm{L})\end{array}$ & $\begin{array}{c}\text { System response } \\
\text { Y: As removal } \\
(\%)\end{array}$ \\
\hline 1 & 5 & 0.31 & 27.5 & 38.125 & 44.8 \\
\hline 2 & 7 & 0.23 & 10 & 26.25 & 24.2 \\
\hline 3 & 7 & 0.4 & 45 & 26.25 & 55.8 \\
\hline 4 & 7 & 0.23 & 45 & 26.25 & 39.6 \\
\hline 5 & 7 & 0.23 & 45 & 50 & 26.5 \\
\hline 6 & 5 & 0.14 & 27.5 & 38.125 & 26.4 \\
\hline 7 & 9 & 0.31 & 62.5 & 14.375 & 48.1 \\
\hline 8 & 7 & 0.23 & 45 & 26.25 & 38.5 \\
\hline 9 & 5 & 0.14 & 27.5 & 14.375 & 40.6 \\
\hline 10 & 7 & 0.23 & 45 & 2.5 & 54.7 \\
\hline 11 & 9 & 0.14 & 27.5 & 38.125 & 2.1 \\
\hline 12 & 9 & 0.14 & 62.5 & 14.375 & 27.6 \\
\hline 13 & 7 & 0.23 & 45 & 26.25 & 39.6 \\
\hline 14 & 7 & 0.23 & 80 & 26.25 & 48.3 \\
\hline 15 & 3 & 0.23 & 45 & 26.25 & 62.4 \\
\hline 16 & 5 & 0.31 & 62.5 & 14.375 & 71.4 \\
\hline 17 & 9 & 0.31 & 62.5 & 38.125 & 33.3 \\
\hline 18 & 5 & 0.31 & 62.5 & 38.125 & 60.2 \\
\hline 19 & 5 & 0.14 & 62.5 & 14.375 & 52.1 \\
\hline 20 & 5 & 0.14 & 62.5 & 38.125 & 40.9 \\
\hline 21 & 5 & 0.31 & 27.5 & 14.375 & 56.3 \\
\hline 22 & 7 & 0.23 & 45 & 26.25 & 39.5 \\
\hline 23 & 9 & 0.14 & 62.5 & 38.125 & 11.1 \\
\hline 24 & 11 & 0.23 & 45 & 26.25 & 13.2 \\
\hline 25 & 7 & 0.23 & 45 & 26.25 & 39.6 \\
\hline 26 & 9 & 0.14 & 27.5 & 14.375 & 19.6 \\
\hline 27 & 7 & 0.23 & 45 & 26.25 & 39.7 \\
\hline 28 & 7 & 0.05 & 45 & 26.25 & 15.2 \\
\hline 29 & 9 & 0.31 & 27.5 & 14.375 & 38.6 \\
\hline 30 & 9 & 0.31 & 27.5 & 38.125 & 22.4 \\
\hline
\end{tabular}


Table 3. ANOVA results for As(V) adsorption on amino-MIL-68(Al).

\begin{tabular}{lllllll}
\hline Source & Sum of Squares & df & Mean Square & F-value & p-value & Effect $(\%)$ \\
\hline Model & 7927.32 & 14 & 566.24 & 2389.17 & $<0.0001$ & \\
$\mathrm{~A}^{*}$ & 3467.68 & 1 & 3467.68 & 14631.48 & $<0.0001$ & -41.34553 \\
$\mathrm{~B}$ & 2320.48 & 1 & 2320.48 & 9791.01 & $<0.0001$ & 28.7074 \\
$\mathrm{C}$ & 838.1 & 1 & 838.1 & 3536.29 & $<0.0001$ & 9.98696 \\
$\mathrm{D}$ & 1198.77 & 1 & 1198.77 & 5058.08 & $<0.0001$ & -14.29214 \\
$\mathrm{AB}$ & 5.24 & 1 & 5.24 & 22.12 & 0.0003 & 0.398128 \\
$\mathrm{AC}$ & 22.8 & 1 & 22.8 & 96.2 & $<0.0001$ & -1.626429 \\
$\mathrm{AD}$ & 17.85 & 1 & 17.85 & 75.32 & $<0.0001$ & -1.279025 \\
$\mathrm{BC}$ & 3.94 & 1 & 3.94 & 16.64 & 0.001 & 0.297481 \\
$\mathrm{BD}$ & 2.03 & 1 & 2.03 & 8.58 & 0.0104 & 0.154466 \\
$\mathrm{CD}$ & 2.03 & 1 & 2.03 & 8.57 & 0.0104 & 0.144137 \\
$\mathrm{~A}^{2}$ & 4.24 & 1 & 4.24 & 17.91 & 0.0007 & -0.178448 \\
$\mathrm{~B}^{2}$ & 18.37 & 1 & 18.37 & 77.5 & $<0.0001$ & -0.783167 \\
$\mathrm{C}^{2}$ & 16.7 & 1 & 16.7 & 70.46 & $<0.0001$ & -0.700305 \\
$\mathrm{D}^{2}$ & 2.56 & 1 & 2.56 & 10.81 & 0.005 & -0.106394 \\
Residual & 3.56 & 15 & 0.237 & & & \\
Lack of Fit & 2.53 & 10 & 0.2527 & 1.23 & 0.4341 &
\end{tabular}

* A, B, C and D represent the independent variables defined in Table 1. 

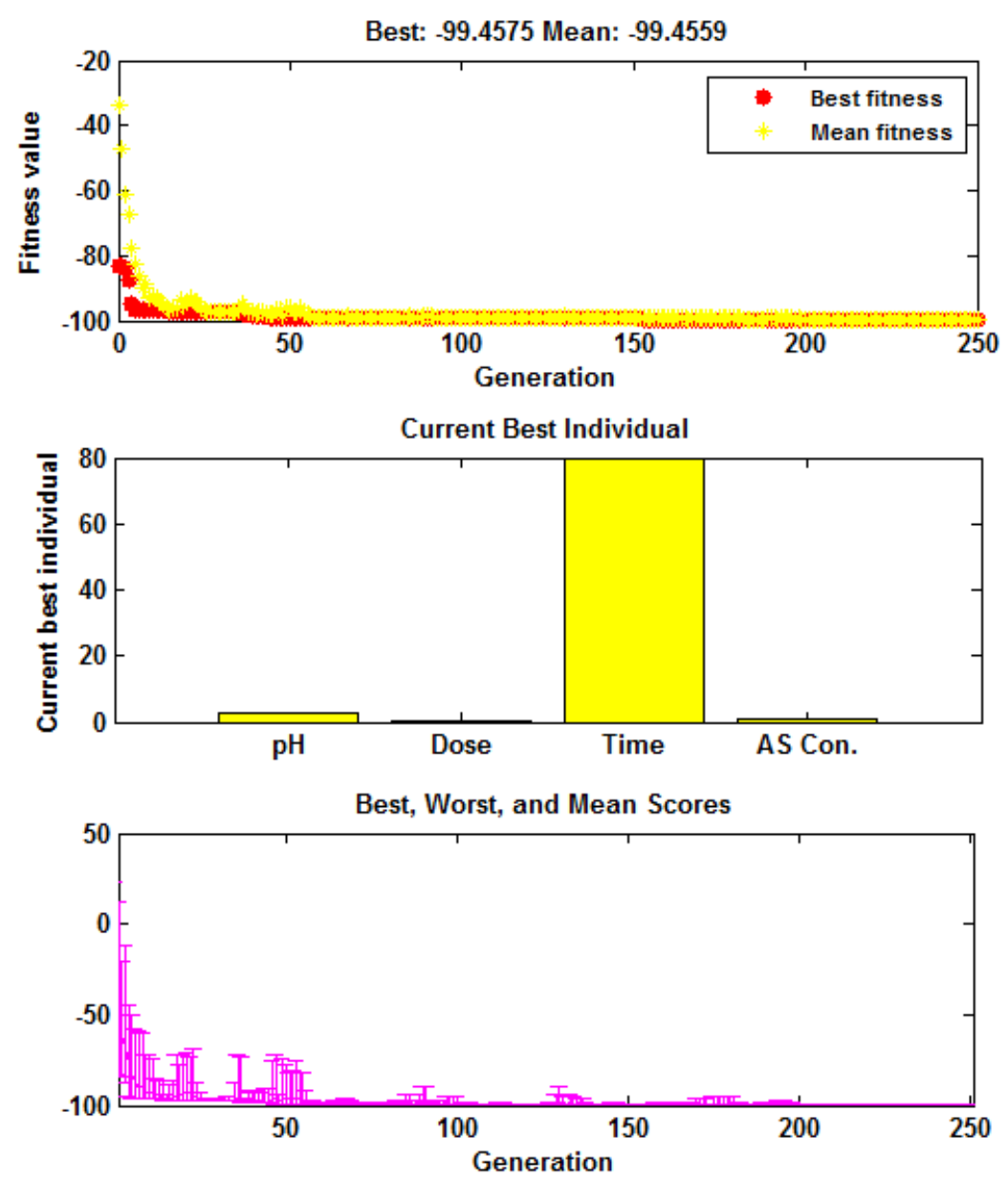

Fig. 5. Output of GA method for optimization of independent variables in $\mathrm{As}(\mathrm{V})$ adsorption process on amino-MIL-68(Al).

\subsection{Interaction of independent variables on the efficiency of $\operatorname{As}(V)$ removal}

The effect of the interaction of solution $\mathrm{pH}$ and MOF dose on $\mathrm{As}(\mathrm{V})$ removal efficiency is shown in Fig. 6. Clearly, with decreasing $\mathrm{pH}$ in the range of 3 to 11 and with increasing MOF dose in the range of 0.05 to $0.4 \mathrm{~g} / \mathrm{L}$, the $\mathrm{As}(\mathrm{V})$ removal efficiency is significantly improved. So that at solution $\mathrm{pH}$ of 11 and MOF dose of $0.05 \mathrm{~g} / \mathrm{L}$, the $\mathrm{As}(\mathrm{V})$ removal efficiency is about $9.5 \%$. However, at a solution $\mathrm{pH}$ of 3 and in the presence of $0.4 \mathrm{~g} / \mathrm{L} \mathrm{MOF}$ the efficiency of As $(\mathrm{V})$ removal by the model is predicted to be about $99.5 \%$. In addition, as can be seen in the presence of $1 \mathrm{~g} / \mathrm{L}$ of MOF, the efficiency of $\mathrm{As}(\mathrm{V})$ removal at $\mathrm{pHs}$ of 5, 7, 9 and 11 is 88.4, $76.9,68.2$ and $54.2 \%$, respectively. 
The $\mathrm{pH}$ of the solution is one of the operational factors that affects the efficiency of the adsorption process by affecting the properties of the adsorbent surface and the distribution of the dominant species of $\mathrm{As}(\mathrm{V})$ [45]. $\mathrm{As}(\mathrm{V})$ is mainly present in the form of $\mathrm{H}_{2} \mathrm{AsO}_{4}^{-}$in aqueous solutions with a $\mathrm{pH}$ in the range of 3-6. However, with increasing $\mathrm{pH}(\mathrm{pH}>7)$, the predominant forms will be $\mathrm{HAsO}_{4}^{2-}$ and $\mathrm{AsO}_{4}^{3-}$ [46]. The zeta potential of amino-MIL-68(Al) at pHs of 3, $5,7,9$, and 11 was measured to be $+11.8,+9.5,+4.6,+1.2$, and $-2.3 \mathrm{mV}$, respectively. Accordingly, the pHzpc for the amino-MIL-68(Al) was determined at 9.2. In other words, in a sample solution with a $\mathrm{pH}$ greater than 9.2, the amino-MIL-68(Al) surface charge has a negative state. Accordingly, the amino-MIL-68(Al) efficiency for adsorption of As(V) anionic species at high $\mathrm{pH}(\mathrm{pH}>9.2)$ is limited. However, the decrement in $\mathrm{As}(\mathrm{V})$ removal efficiency with increasing solution $\mathrm{pH}$ in the range of 3 to 9 can be related to the decrease of surface potential of amino-MIL-68(Al), which reduces the electrostatic attraction between the As(V) anions and the MOF surface [47]. Accordingly, the optimal $\mathrm{pH}$ in the present study was predicted to be 3, which is consistent with the results of some previous studies. Vu et al. have studied the effect of $\mathrm{pH}$ in the range of 3 to 11 on the removal efficiency of As(V) with MIL53(Fe). In their study, the most $\mathrm{As}(\mathrm{V})$ removal was reported at $\mathrm{pH}$ 5, 3, 9, and 11, respectively [48]. In the study of Wang et al., the highest $\mathrm{As}(\mathrm{V})$ adsorption on UiO-66 was obtained at $\mathrm{pH}$ between 1 and 3 [13]. In addition, in the study of Wu et al., The highest As(V) removal efficiency on MIL-88A microrods was observed at $\mathrm{pH} 3$ and 5 [49].

As can be seen in Fig. 6, at a solution $\mathrm{pH}$ of 3, the As(V) removal efficiency in the presence of MOF doses of $0.05,0.1375,0.225,0.3125$ and $0.4 \mathrm{~g} / \mathrm{L}$ is about $61.2,74.5,83,92.1$ and 99.5 $\%$, respectively. Clearly, as the adsorbent dose increases, the number of available adsorption sites increases, resulting in improved removal efficiencies [50]. Improvement of contaminant removal efficiency by increasing the adsorbent dose has been reported by other scholars [45, 51]. The interaction of reaction time and $\mathrm{As}(\mathrm{V})$ concentration on $\mathrm{As}(\mathrm{V})$ removal efficiency is 
shown in Fig. 7. As can be seen, increasing the reaction time and decreasing the As(V) concentration improve the removal efficiency. Accordingly, the efficiency of As(V) removal at the initial concentration of $50 \mathrm{mg} / \mathrm{L}$ after 10 and $80 \mathrm{~min}$ of the reaction is about 45.7 and 85.2 \%, respectively. On the other hand, the removal efficiency of $\mathrm{As}(\mathrm{V})$ at initial concentrations of 2.5 and $50 \mathrm{mg} / \mathrm{L}$ after $80 \mathrm{~min}$ of reaction is about 99.5 and $85.2 \%$, respectively. At a constant dose of adsorbent, the removal efficiency at high concentrations of $\mathrm{As}(\mathrm{V})$ is reduced due to the limited active adsorption sites at the surface of MOF. In this regard, the results reported by other researchers are consistent with our study [45, 49].
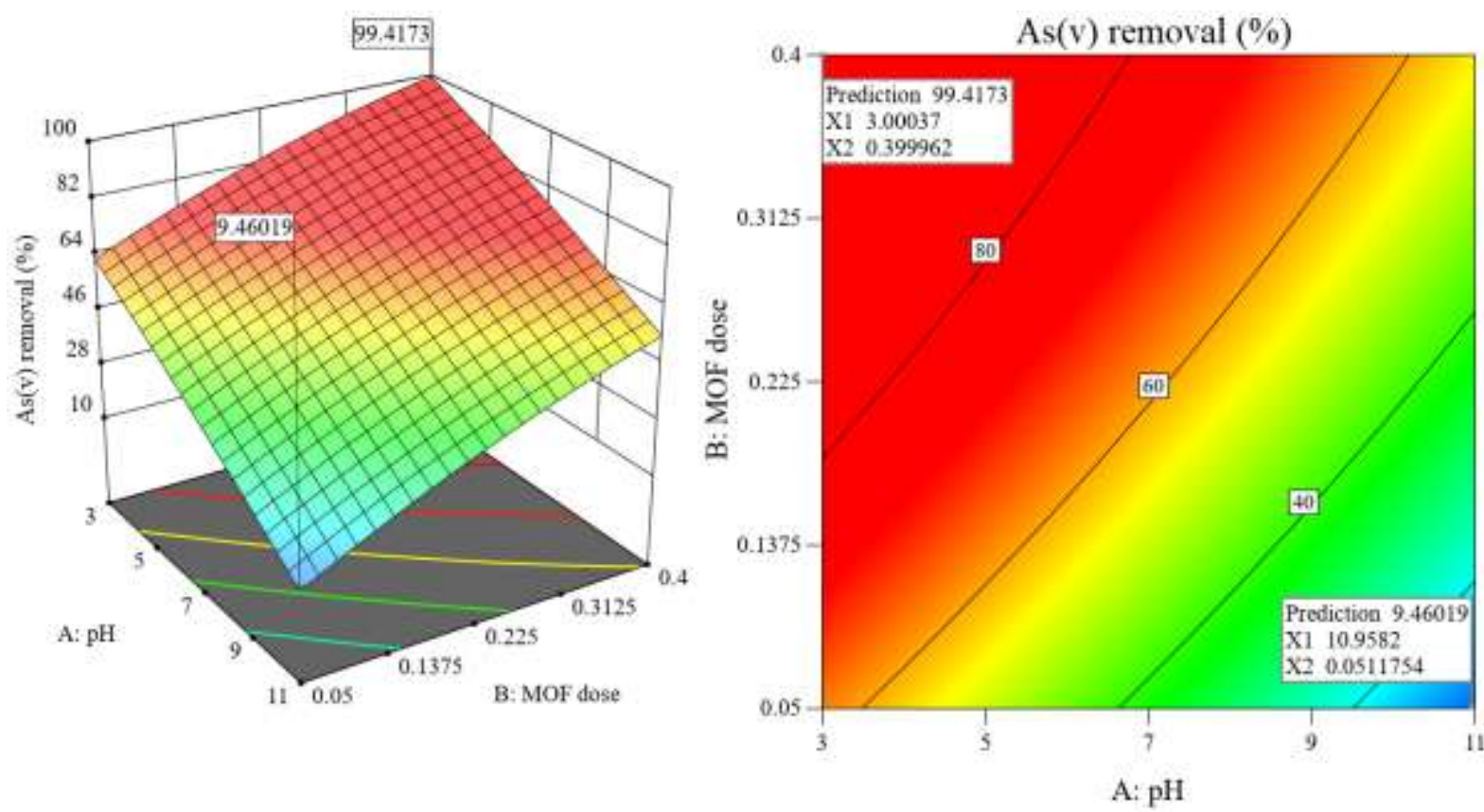

Fig. 6. Interaction of $\mathrm{pH}$ and $\mathrm{MOF}$ dose on system response $(\mathrm{As}(\mathrm{V})=2.5 \mathrm{mg} / \mathrm{L}$, Time $=80$ $\min )$. 

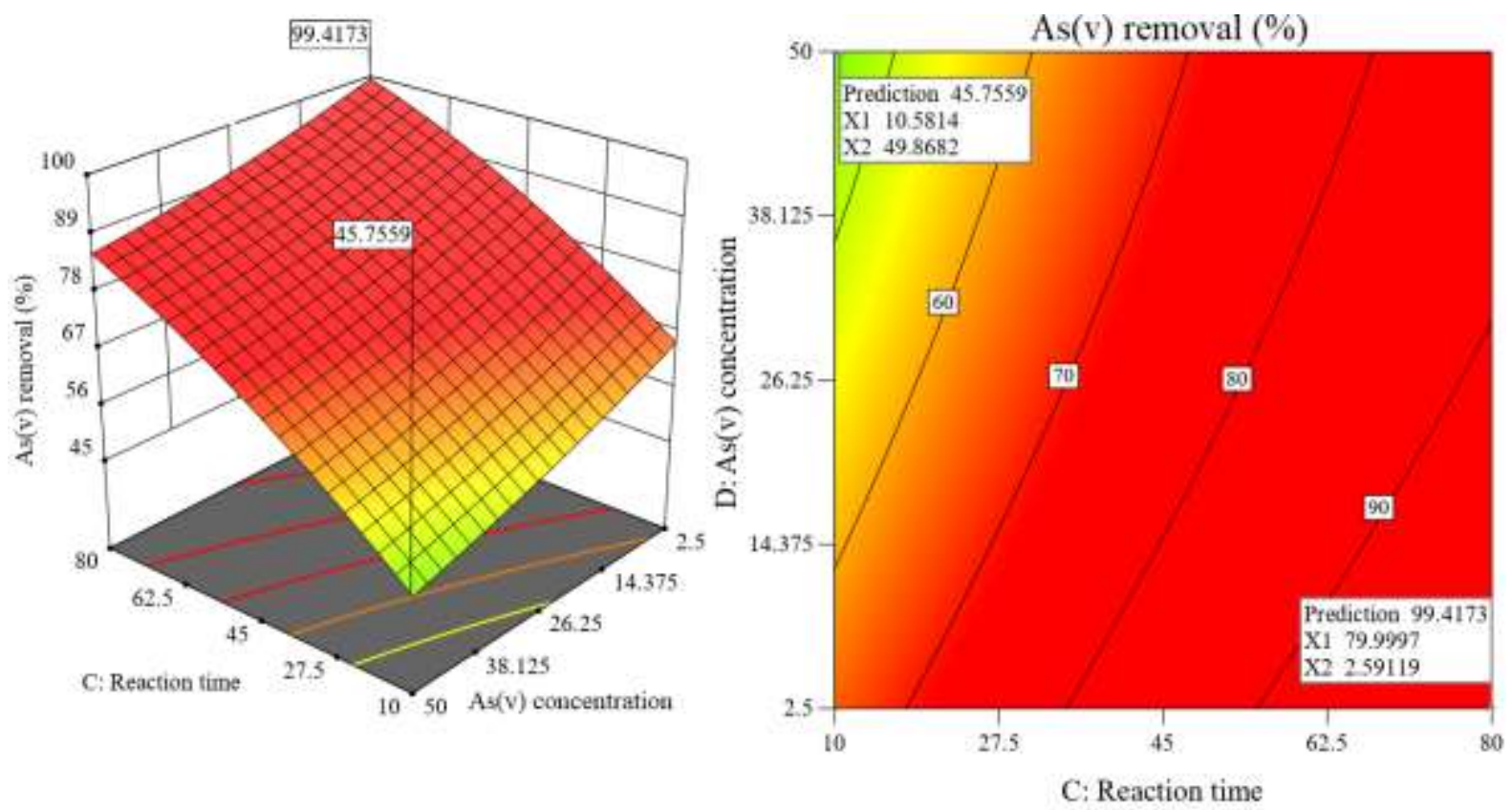

Fig. 7. Interaction of reaction time and $\mathrm{As}(\mathrm{V})$ concentration on system response $(\mathrm{pH}=3, \mathrm{MOF}$ dose $=0.4 \mathrm{~g} / \mathrm{L})$

\subsection{Adsorption isotherms and kinetics}

The study of adsorption isotherms can reveal valuable information about the adsorption capacity and behavior of an adsorbent in interaction with an adsorbate [52]. For this purpose, under optimal conditions, the experimental data were evaluated with Freundlich, Langmuir, Temkin and Dublin-Radushkevich isotherm models. The Langmuir isotherm describes the monolayer adsorption on the homogeneous surface of the adsorbent. The Freundlich isotherm assumes that adsorption is not monolayer and describes equilibrium at heterogeneous surfaces [53]. The nonlinear and linear models of the Langmuir isotherm are presented in Eqs. 5 and 6. For Freundlich isotherm, nonlinear and linear models can be seen in Eqs. 7 and 8.

$$
\begin{aligned}
& \mathrm{q}_{e}=\frac{\mathrm{q}_{\max } \mathrm{K}_{\mathrm{L}} \mathrm{C}_{e}}{1+\mathrm{K}_{\mathrm{L}} \mathrm{C}_{\mathrm{e}}} \\
& \frac{\mathrm{Ce}}{\mathrm{qe}}=\frac{1}{\mathrm{~K}_{\mathrm{L}} \mathrm{q}_{\max }}+\frac{\mathrm{Ce}}{\mathrm{q}_{\max }} \\
& \mathrm{q}_{\mathrm{e}}=\mathrm{K}_{\mathrm{f}} \mathrm{C}_{\mathrm{e}}^{\frac{1}{\mathrm{n}}} \\
& \text { Loq } \mathrm{q}_{\mathrm{e}}=\log \mathrm{K}_{\mathrm{F}}+\frac{1}{\mathrm{n}}
\end{aligned}
$$


where qe is the mg of $\mathrm{As}(\mathrm{V})$ adsorbed per $\mathrm{g}$ of amino-MIL-68(Al) $(\mathrm{mg} / \mathrm{g}) . \mathrm{C}_{\mathrm{e}}$ indicates the equilibrium concentration of $\mathrm{As}(\mathrm{V})(\mathrm{mg} / \mathrm{L}) . \mathrm{q}_{\max }$ represents the maximum adsorption capacity $(\mathrm{mg} / \mathrm{g})$ and $\mathrm{K}_{\mathrm{L}}$ represents the Langmuir equilibrium constant $(1 / \mathrm{mg}) . \mathrm{K}_{\mathrm{f}}$ and $1 / \mathrm{n}$ show the adsorption capacity $(1 / \mathrm{mg})$ and adsorption intensity, respectively. $\mathrm{K}_{\mathrm{f}}$ and $\mathrm{n}$ are determined from the nonlinear graph qe vs. Ce and the linear graph $\log \mathrm{q}_{\mathrm{e}} \mathrm{vs} . \log \mathrm{C}_{\mathrm{e}}$

The Temkin isotherm describes the process on a heterogeneous surface with adsorption sites with the same bond energy. Eqs. 9 and 10 describe the nonlinear and linear models of this isotherm [27]. The Dublin-Radushkevich isotherm describes the adsorption process on the heterogeneous surfaces. However, unlike the Freundlich isotherm, the absorption energy dissipation in this isotherm is linear [54]. The nonlinear and linear models of the DublinRadushkevich isotherm are presented in Eqs. 11 and 12.

$$
\begin{aligned}
& \mathrm{q}_{\mathrm{e}}=\frac{\mathrm{RT}}{\mathrm{B}} \ln \mathrm{K}_{\mathrm{T}} \mathrm{C}_{\mathrm{e}} \\
& \mathrm{q}_{\mathrm{e}}=\mathrm{B} \ln \mathrm{K}_{\mathrm{T}}+\mathrm{B} \ln \mathrm{C}_{\mathrm{e}} \\
& \mathrm{q}_{\mathrm{e}}=\mathrm{q}_{\max } \exp ^{\beta \varepsilon^{2}} \\
& \ln \mathrm{q}_{\mathrm{e}}=\ln \mathrm{q}_{\max }-\beta \varepsilon^{2} \\
& \varepsilon=\mathrm{RT} \operatorname{Ln}\left(1+\frac{1}{\mathrm{C}_{\mathrm{e}}}\right) \\
& \mathrm{E}=\frac{1}{\sqrt{2 \beta}}
\end{aligned}
$$

where B represents the Temkin isotherm constant $(\mathrm{J} / \mathrm{mol}) . \mathrm{K}_{\mathrm{T}}$ is the maximum bond energy (1/mg). $\mathrm{R}$ and $\mathrm{T}$ are also related to gas constant $(8.314 \mathrm{~J} / \mathrm{K} \mathrm{mol})$ and temperature $(\mathrm{K})$, respectively. $\mathrm{q}_{\max }$ is the monolayer adsorption capacity in the Dublin-Radushkevich isotherm $(\mathrm{mg} / \mathrm{g}) . \beta$ also represents the adsorption energy constant in this isotherm. $\varepsilon$ is the Polanyi potential calculated by Eq. 13. In the Dublin-Radushkevich isotherm, the most probable free adsorption energy (E, J/mol) is calculated by Eq. 14. E $<8$ and $8<\mathrm{E}<16 \mathrm{~kJ} / \mathrm{mol}$ show a physical nature and chemical nature, respectively. 
The nonlinear form of isotherm models is plotted in Fig. 8(a). Table 4 also presents the values of different parameters and coefficients for the studied models. The results show that the Langmuir isotherm $\left(\mathrm{R}^{2}=0.9998\right)$ describes the experimental data better than other models. Accordingly, the adsorption of $\mathrm{As}(\mathrm{V})$ on amino-MIL-68(Al) is homogeneous monolayer process $[14,55]$. The maximum adsorption capacity of $\mathrm{As}(\mathrm{V})$ by the Langmuir isotherm was obtained to be $74.29 \mathrm{mg} / \mathrm{g}$, which is higher than the reported values for $\mathrm{ZrO}_{2}$-sawdust $(12 \mathrm{mg} / \mathrm{g})$ [56], organic biochar (16.2 mg/g) [57], $\mathrm{CuO}$ nanoparticles $(22.6 \mathrm{mg} / \mathrm{g})$ [58], and $\mathrm{Fe}_{3} \mathrm{O}_{4}-\mathrm{RGO}-$ $\mathrm{MnO}_{2}(12.22 \mathrm{mg} / \mathrm{g})$ [59]. In addition, the maximum adsorption capacity of $\mathrm{As}(\mathrm{V})$ on the synthesized amino-MIL-68(Al) compared to other MOFs including MIL-53(Fe) $(21.27 \mathrm{mg} / \mathrm{g})$ [48], MIL-100(Fe) (110 mg/g) [60], Fe-BTC (12.29 mg/g) [61], $\mathrm{Fe}_{3} \mathrm{O}_{4} @ \mathrm{MIL}-101(\mathrm{Cr})(80$ mg/g) [62], ZIF-8 (90.92 mg/g) [63], Co-MOF (96.1 mg/g) [64], $\mathrm{Fe}_{3} \mathrm{O}_{4} @ \mathrm{UiO}-66$ (73.2 mg/g) [65], MOF-808 (24.8 mg/g) [31], UiO-66 (68 mg/g) [55] and UiO-66-(SH)2 (10 mg/g) [66] is an acceptable value.

Determining the reaction rate and its mechanism depends on conducting kinetic studies. Different types of models have been developed to describe the kinetics of adsorption process. In the present study, the adsorption kinetic of $\mathrm{As}(\mathrm{V})$ on amino-MIL-68(Al) were studied and fitted with three different kinetic models including pseudo-first order [67], pseudo-second order [68], and intraparticle diffusion models [69]. The nonlinear equations of these kinetic models are shown in Eqs. 15 to 17, respectively.

$\mathrm{q}_{\mathrm{t}}=\mathrm{q}_{\mathrm{e}}\left(1-\mathrm{e}^{-\mathrm{k}_{1} \mathrm{t}}\right)$

$\mathrm{q}_{\mathrm{t}}=\frac{\mathrm{k}_{2} \mathrm{q}_{\mathrm{e}}^{2} \mathrm{t}}{1+\mathrm{k}_{2} \mathrm{q}_{\mathrm{e}} \mathrm{t}}$

$\mathrm{q}_{\mathrm{t}}=\mathrm{k}_{\mathrm{i}} \mathrm{t}^{0 / 5}+\mathrm{C}$

where $\mathrm{q}_{\mathrm{t}}(\mathrm{mg} / \mathrm{g})$ indicates the absorption capacity at time $\mathrm{t} . \mathrm{q}_{\mathrm{e}}(\mathrm{mg} / \mathrm{g})$ is also related to the absorption capacity at equilibrium time. $\mathrm{k}_{1}(1 / \mathrm{min})$ and $\mathrm{k}_{2}(\mathrm{~g} / \mathrm{mg} \cdot \mathrm{min})$ are the rates constant of 
adsorption for pseudo-first-order and second-first-order kinetic models, respectively. $\mathrm{k}_{\mathrm{i}}$ $\left(\mathrm{mg} / \mathrm{g} \cdot \mathrm{min}^{0 / 5}\right)$ expresses the rate constant of intraparticle diffusion kinetic model.

Fig. 8(b) and Table 5 show the data obtained from the study of adsorption kinetic in the nonlinear form of the models. As can be seen, the experimental data are well consistent with the pseudo-second-order nonlinear model $\left(\mathrm{R}^{2}=0.9822\right)$, which indicates that the chemical adsorption mechanism dominates the adsorption process [55]. The results of recent studies show that As(V) adsorption on MOFs (Fe/Mg-MIL-88B(n) [70], Fe-Co MOF-74 [47], Fe/AlBDC-NH $\mathrm{NH}_{2}$ [71] and UiO-66/PAN membrane [72]) is generally well described by pseudosecond-order kinetic model.
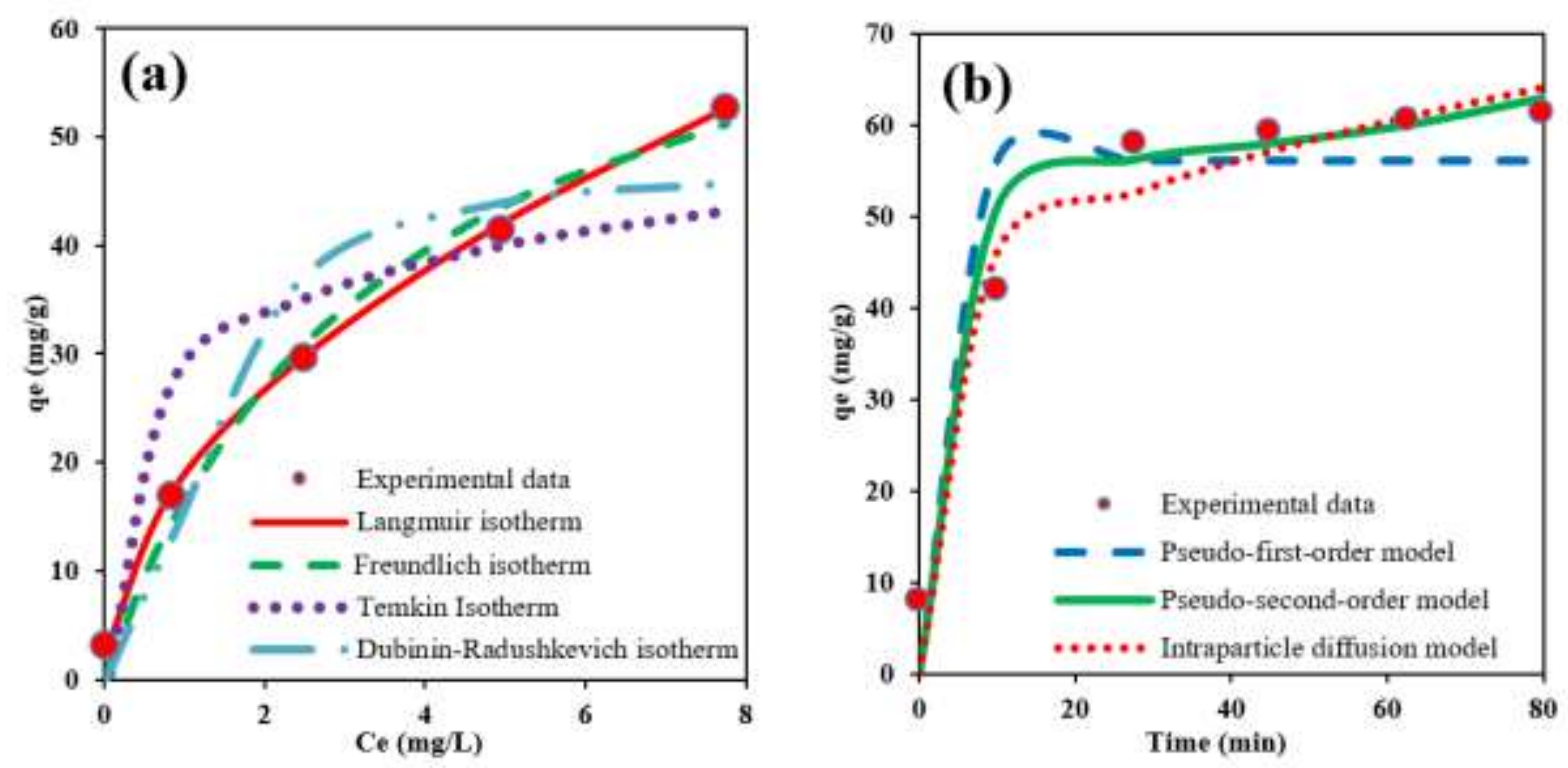

Fig. 8. Nonlinear isotherm models $(\mathrm{pH}=3)(\mathrm{a})$, and nonlinear adsorption kinetic models $(\mathrm{pH}$ $=3, \operatorname{As}(\mathrm{V})=50 \mathrm{mg} / \mathrm{L})(\mathrm{b})$ for $\mathrm{As}(\mathrm{V})$ adsorption on amino-MIL-68(Al). 
Table 4. Isotherm coefficients and parameters of As(V) adsorption on amino-MIL-68(Al).

\begin{tabular}{lll}
\hline Adsorption isotherms & parameters & Parameter values \\
\hline Freundlich & $\mathrm{K}_{\mathrm{F}}(\mathrm{mg} / \mathrm{g})$ & 18.731 \\
$1 / \mathrm{n}$ & 0.504 \\
Langmuir & $\mathrm{R}^{2}$ & 0.9921 \\
& $\mathrm{q}_{\max }(\mathrm{mg} / \mathrm{g})$ & 74.29 \\
& $\mathrm{~K}_{\mathrm{L}}(\mathrm{L} / \mathrm{mg})$ & 0.286 \\
Temkin & $\mathrm{R}^{2}$ & 0.9998 \\
& $\mathrm{~K}_{\mathrm{T}}(\mathrm{L} / \mathrm{g})$ & 135.878 \\
& $\mathrm{~b}(\mathrm{~J} / \mathrm{mol})$ & 2166.189 \\
Dublin-Radushkevich & $\mathrm{R}^{2}$ & 0.8355 \\
& $\mathrm{q}_{\max }(\mathrm{mg} / \mathrm{g})$ & 47.166 \\
& $\left.\beta(\mathrm{mol})^{2} / \mathrm{J}^{2}\right)$ & 0.0286 \\
& $\mathrm{R}^{2}$ & 0.9471 \\
& $\mathrm{E}$ & 4.181 \\
\hline
\end{tabular}

Table 5. Kinetic parameters of As(V) adsorption on amino-MIL-68(Al).

\begin{tabular}{lll}
\hline Adsorption kinetics & parameters & Parameter values \\
\hline Pseudo-first order model & $\mathrm{qe}(\mathrm{mg} / \mathrm{g})$ & 56.213 \\
& $\mathrm{~K}_{1}\left(\mathrm{~min}^{-1}\right)$ & 0.413 \\
Pseudo-second order model & $\mathrm{R}^{2}$ & 0.9584 \\
& $\mathrm{qe}(\mathrm{mg} / \mathrm{g})$ & 58.174 \\
& $\mathrm{~K}_{2}\left(\mathrm{~g} \cdot \mathrm{mg}^{-1} \mathrm{~min}^{-1}\right)$ & 0.221 \\
Intraparticle diffusion model & $\mathrm{R}^{2}$ & 0.9822 \\
& $\mathrm{C}$ & 36.303 \\
& $\mathrm{~K}_{\mathrm{i}}\left(\mathrm{mg} / \mathrm{gmin}^{0.5}\right)$ & 0.742 \\
& $\mathrm{R}^{2}$ & 0.9796 \\
\hline
\end{tabular}

\subsection{Adsorption thermodynamic}

Thermodynamic parameters provide useful information about whether the reactions are endothermic or exothermic, whether the processes are spontaneous or not, and the entropy changes in the process. Thermodynamic parameters were determined using Eqs. 18 to 20 [73].

$$
\begin{aligned}
& \Delta \mathrm{G}^{\circ}=-\mathrm{RT} \ln \mathrm{K}_{\mathrm{c}} \\
& \ln \mathrm{K}_{\mathrm{c}}=\frac{\Delta \mathrm{S}^{\circ}}{\mathrm{R}}-\frac{\Delta \mathrm{H}^{\circ}}{\mathrm{RT}}
\end{aligned}
$$


$\mathrm{K}_{\mathrm{c}}=\frac{\mathrm{q}_{\mathrm{e}}}{\mathrm{C}_{\mathrm{e}}}$

where $\Delta \mathrm{G}^{\circ}$ is the standard Gibbs free energy $(\mathrm{kJ} / \mathrm{mol}), \mathrm{K}_{\mathrm{c}}$ is the distribution coefficient, which was calculated by Eq. $20 . \mathrm{T}$ also represents the absolute temperature of the solution $(\mathrm{K}) . \Delta \mathrm{S}^{\circ}$ $(\mathrm{J} / \mathrm{mol} . \mathrm{K})$ and $\Delta \mathrm{H}^{\circ}(\mathrm{kJ} / \mathrm{mol})$ are the entropy and enthalpy parameters. In Eq. 20, $\mathrm{q}_{\mathrm{e}}$ and $\mathrm{C}_{\mathrm{e}}$ represent the adsorption capacity $(\mathrm{mg} / \mathrm{g})$ and $\mathrm{As}(\mathrm{V})$ concentration $(\mathrm{mg} / \mathrm{L})$ in equilibrium, respectively. The thermodynamic parameters of $\mathrm{As}(\mathrm{V})$ adsorption on amino-MIL-68(Al) are presented in Table 6 . As can be seen, the value of $\Delta \mathrm{G}^{\circ}$ becomes more negative with increasing temperature in the range of 25 to $50{ }^{\circ} \mathrm{C}$. Accordingly, $\mathrm{As}(\mathrm{V})$ adsorption on prepared MOF is a spontaneous process that is improved by higher temperatures [71]. Given the positive value of $\Delta \mathrm{H}^{\circ}$, it is clear that the nature of the $\mathrm{As}(\mathrm{V})$ adsorption on the amino-MIL-68(Al) is an endothermic process [74]. In other words, higher temperatures accelerate mass-transfer and process kinetics, resulting in an improved adsorption process. Also, a positive value of $\Delta \mathrm{S}^{\circ}$ means that chaos increases at the solid-liquid interface. In such a situation ion exchange occurs during As(V) uptake [75].

Table. 6. Thermodynamic parameters of As(V) adsorption on amino-MIL-68(Al)

\begin{tabular}{llll}
\hline $\mathrm{T}(\mathrm{K})$ & $\Delta \mathrm{G}^{\circ}(\mathrm{KJ} / \mathrm{mol})$ & $\Delta \mathrm{H}^{\circ}(\mathrm{KJ} / \mathrm{mol})$ & $\Delta \mathrm{S}^{\circ}(\mathrm{J} /(\mathrm{mol} . \mathrm{K}))$ \\
\hline 298 & -4.076 & 70.718 & 0.251 \\
303 & -5.370 & & \\
308 & -6.874 & & \\
313 & -8.194 & & \\
318 & -8.895 & & \\
323 & -10.478 & & \\
\hline
\end{tabular}

\subsection{Reusability of amino-MIL-68(Al)}

High reusability is an important feature for adsorbents to be used on an industrial scale to treat polluted water. In recent years, many efforts have been made to develop water-stable MOFs. In the present study, the efficiency of the synthesized MOF for $\operatorname{As}(\mathrm{V})$ adsorption in ten consecutive reuse cycles was investigated under optimal conditions. MOF regeneration was 
performed after each reuse round using 0.01 M nitric acid solution [60, 70]. As shown in Fig. 9(a), the MOF efficiency for As(V) removal after ten reuses is not significantly reduced. So that the As(V) removal efficiency in the first and tenth use cycle is $99.87 \%$ and $80.2 \%$, respectively. These results indicate that the synthesized MOF has a high reusability for As(V) adsorption. The slight decrement in removal efficiency may be due to the reduction in the number of adsorption sites after each regeneration as well as the loss of MOF during separation and washing [47].

\subsection{Effect of interfering anions on $\mathrm{As}(\mathrm{V})$ removal efficiency}

Natural waters and industrial wastewater are always contaminated with a variety of ioninterfering species that dramatically affect the efficiency of the adsorption process. In this study, the effect of chloride, nitrate, sulfate, and phosphate anions at a constant concentration of $1 \mathrm{mM}$ and under optimal laboratory conditions $(\mathrm{pH}=3$, MOF dose $=0.4 \mathrm{~g} / \mathrm{L}$, reaction time $=80 \mathrm{~min}$ and $\mathrm{As}(\mathrm{V})$ concentration $=2.5 \mathrm{mg} / \mathrm{L})$ was investigated on the efficiency of $\mathrm{As}(\mathrm{V})$ removal, the results of which are presented in Fig. 9(b). As can be seen, the presence of chloride, nitrate, and sulfate anions in the samples solution does not have much interference with $\mathrm{As}(\mathrm{V})$ adsorption on MOF. However, in the presence of phosphate, a significant reduction is observed in the $\mathrm{As}(\mathrm{V})$ removal efficiency. Phosphate competes with $\mathrm{As}(\mathrm{V})$ for active sites at the MOF surface, resulting in inhibition of $\mathrm{As}(\mathrm{V})$ adsorption. The high intervening effect of phosphate with $\mathrm{As}(\mathrm{V})$ adsorption can be attributed to similar physicochemical properties of these two elements [55]. 

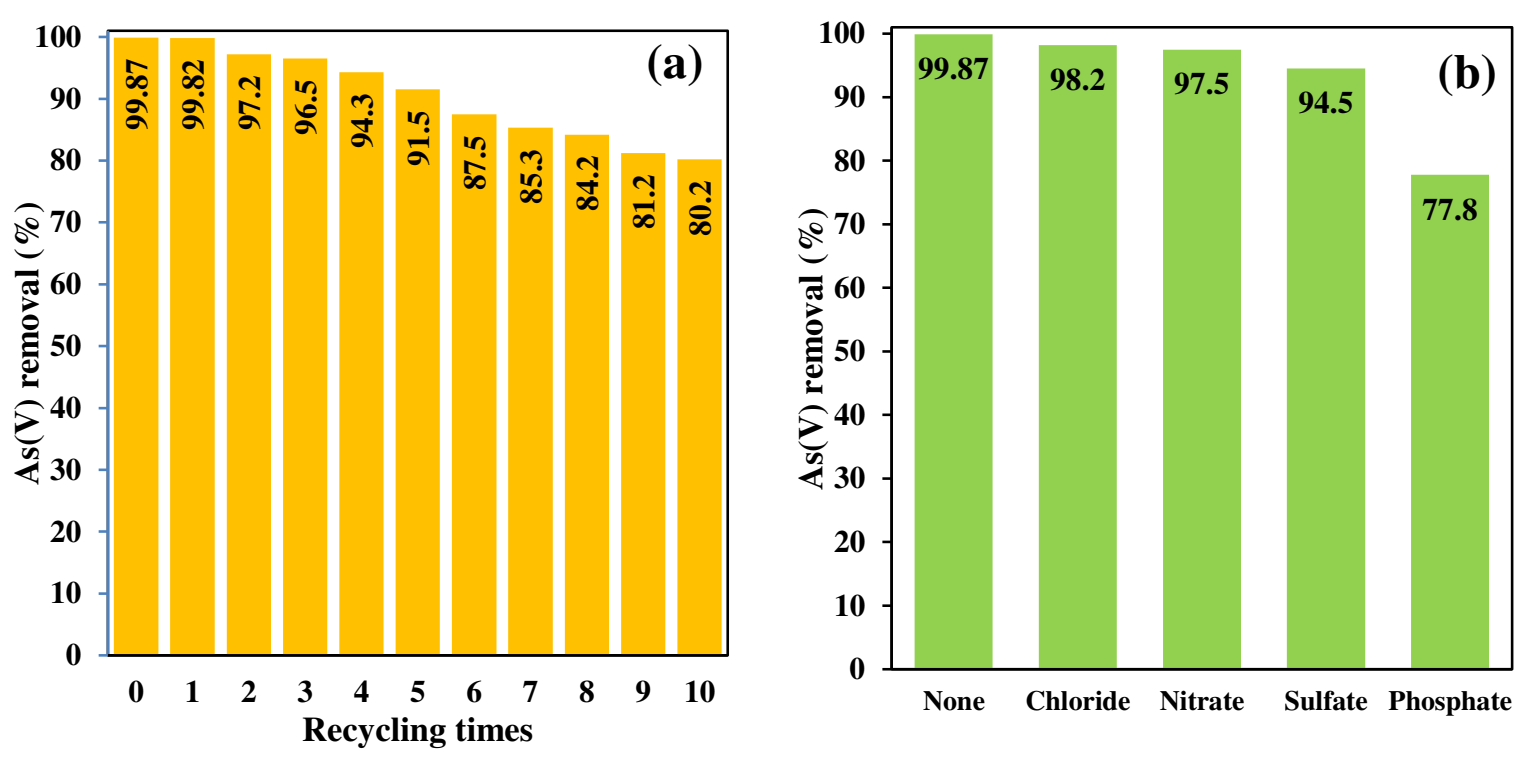

Fig. 9. As(V) removal efficiency by amino-MIL-68(Al) for ten consecutive reuse cycles under optimal conditions (a). Interventional effect of anions on $\mathrm{As}(\mathrm{V})$ removal efficiency (The oncentration of anions $=1 \mathrm{mM})(\mathrm{b})$.

\section{Conclusion}

In the present study, amino-MIL-68(Al) was prepared by solvothermal method using 2aminoterephthalic acid as a ligand. FESEM, XRD, FTIR and EDX-mapping analysis confirmed the synthesis of MOF structures. The results of $\mathrm{N}_{2}$ adsorption/desorption isotherm data showed that the BET surface area of the synthesized MOF is $>1000 \mathrm{~m}^{2} / \mathrm{g}$. Experimental As(V) removal efficiency under optimal conditions $(\mathrm{pH}=3, \mathrm{MOF}$ dose $=0.4 \mathrm{~g} / \mathrm{L}$, reaction time $=80 \mathrm{~min}$ and As $(\mathrm{V})$ concetration $=2.5 \mathrm{mg} / \mathrm{L})$ was obtained $99.87 \%$. Experimental data were fitted with the nonlinear form of isothermand kinetic models. The results showed that the adsorption of $\mathrm{As}(\mathrm{V})$ fits well with the Langmuir model. Accordingly, the maximum As(V) adsorption capacity was obtained $74.29 \mathrm{mg} / \mathrm{g}$. The fit of the data with the pseudo-second-order kinetic model showed that the mechanism of $\mathrm{As}(\mathrm{V})$ adsorption has a chemical nature. In addition, thermodynamic studies revealed that $\mathrm{As}(\mathrm{V})$ adsorption is a spontaneous endothermic process. Based on the data of the present study, MOF is a promising and recyclable adsorbent for the removal of As(V) from contaminated water. 


\section{Competing interests}

The authors declare no competing interests.

\section{Acknowledgments}

The authors appreciate the financial support of Hamadan University of Medical Sciences for this research (Grant number 980203641).

\section{References}

[1] R. Amen, H. Bashir, I. Bibi, S.M. Shaheen, N.K. Niazi, M. Shahid, M.M. Hussain, V. Antoniadis, M.B. Shakoor, S.G. Al-Solaimani, H. Wang, J. Bundschuh, J. Rinklebe, A critical review on arsenic removal from water using biochar-based sorbents: The significance of modification and redox reactions, Chemical Engineering Journal, 396 (2020) 125195.

[2] S. Alka, S. Shahir, N. Ibrahim, M.J. Ndejiko, D.-V.N. Vo, F. Abd Manan, Arsenic removal technologies and future trends: a mini review, Journal of cleaner production, 278 (2021) 123805.

[3] S. Ploychompoo, J. Chen, H. Luo, Q. Liang, Fast and efficient aqueous arsenic removal by functionalized $\mathrm{MIL}-100(\mathrm{Fe}) / \mathrm{rGO} / \delta-\mathrm{MnO} 2$ ternary composites: Adsorption performance and mechanism, Journal of Environmental Sciences, 91 (2020) 22-34.

[4] J.J. LeMonte, J.W. Stuckey, J.Z. Sanchez, R. Tappero, J. Rinklebe, D.L. Sparks, Sea Level Rise Induced Arsenic Release from Historically Contaminated Coastal Soils, Environmental Science \& Technology, 51 (2017) 5913-5922.

[5] M.B. Shakoor, N.K. Niazi, I. Bibi, G. Murtaza, A. Kunhikrishnan, B. Seshadri, M. Shahid, S. Ali, N.S. Bolan, Y.S. Ok, Remediation of arsenic-contaminated water using agricultural wastes as biosorbents, Critical Reviews in Environmental Science and Technology, 46 (2016) 467-499.

[6] T. Siddique, N.K. Dutta, N. Roy Choudhury, Nanofiltration for arsenic removal: challenges, recent developments, and perspectives, Nanomaterials, 10 (2020) 1323.

[7] D. Syam Babu, P. Nidheesh, A review on electrochemical treatment of arsenic from aqueous medium, Chemical Engineering Communications, 208 (2021) 389-410.

[8] E. Leiva, E. Leiva-Aravena, C. Rodríguez, J. Serrano, I. Vargas, Arsenic removal mediated by acidic $\mathrm{pH}$ neutralization and iron precipitation in microbial fuel cells, Science of the Total Environment, 645 (2018) 471-481.

[9] E. Çermikli, F. Şen, E. Altıok, J. Wolska, P. Cyganowski, N. Kabay, M. Bryjak, M. Arda, M. Yüksel, Performances of novel chelating ion exchange resins for boron and arsenic removal from saline geothermal water using adsorption-membrane filtration hybrid process, Desalination, 491 (2020) 114504. 
[10] V. Moreira, Y. Lebron, L. Santos, E.C. de Paula, M. Amaral, Arsenic contamination, effects and remediation techniques: A special look onto membrane separation processes, Process Safety and Environmental Protection, 148 (2021) 604-623.

[11] X. Xu, H. Huang, Y. Zhang, Z. Xu, X. Cao, Biochar as both electron donor and electron shuttle for the reduction transformation of Cr (VI) during its sorption, Environmental pollution, 244 (2019) 423-430.

[12] N.K. Niazi, I. Bibi, M. Shahid, Y.S. Ok, E.D. Burton, H. Wang, S.M. Shaheen, J. Rinklebe, A. Lüttge, Arsenic removal by perilla leaf biochar in aqueous solutions and groundwater: an integrated spectroscopic and microscopic examination, Environmental Pollution, 232 (2018) 31-41.

[13] C. Wang, X. Liu, J.P. Chen, K. Li, Superior removal of arsenic from water with zirconium metalorganic framework UiO-66, Scientific reports, 5 (2015) 1-10.

[14] C. Wang, J. Luan, C. Wu, Metal-organic frameworks for aquatic arsenic removal, Water Research, 158 (2019) 370-382.

[15] H. Furukawa, K.E. Cordova, M. O'Keeffe, O.M. Yaghi, The chemistry and applications of metalorganic frameworks, Science, 341 (2013).

[16] F.M. Hinterholzinger, B. Rühle, S. Wuttke, K. Karaghiosoff, T. Bein, Highly sensitive and selective fluoride detection in water through fluorophore release from a metal-organic framework, Scientific reports, 3 (2013) 1-7.

[17] C. Wang, X. Liu, N.K. Demir, J.P. Chen, K. Li, Applications of water stable metal-organic frameworks, Chemical Society Reviews, 45 (2016) 5107-5134.

[18] R.C. Huxford, J. Della Rocca, W. Lin, Metal-organic frameworks as potential drug carriers, Current opinion in chemical biology, 14 (2010) 262-268.

[19] A. Karami, R. Sabouni, M. Ghommem, Experimental investigation of competitive co-adsorption of naproxen and diclofenac from water by an aluminum-based metal-organic framework, Journal of Molecular Liquids, 305 (2020) 112808.

[20] T. Han, Y. Xiao, M. Tong, H. Huang, D. Liu, L. Wang, C. Zhong, Synthesis of CNT@MIL-68(Al) composites with improved adsorption capacity for phenol in aqueous solution, Chemical Engineering Journal, 275 (2015) 134-141.

[21] M.S. Tehrani, R. Zare-Dorabei, Highly efficient simultaneous ultrasonic-assisted adsorption of methylene blue and rhodamine B onto metal organic framework MIL-68 (Al): central composite design optimization, RSC advances, 6 (2016) 27416-27425.

[22] X. Zhao, D. Liu, H. Huang, W. Zhang, Q. Yang, C. Zhong, The stability and defluoridation performance of MOFs in fluoride solutions, Microporous and mesoporous materials, 185 (2014) 72-78. [23] L. Shen, L. Huang, S. Liang, R. Liang, N. Qin, L. Wu, Electrostatically derived self-assembly of $\mathrm{NH} 2$-mediated zirconium MOFs with graphene for photocatalytic reduction of $\mathrm{Cr}$ (vi), RSC Advances, 4 (2014) 2546-2549. 
[24] R. Rani, A. Deep, B. Mizaikoff, S. Singh, Enhanced hydrothermal stability of Cu MOF by post synthetic modification with amino acids, Vacuum, 164 (2019) 449-457.

[25] S. Wu, Y. Ge, Y. Wang, X. Chen, F. Li, H. Xuan, X. Li, Adsorption of Cr(VI) on nano Uio-66NH2 MOFs in water, Environmental Technology, 39 (2018) 1937-1948.

[26] L. Rasuli, M.H. Dehghani, M. Alimohammadi, K. Yaghmaeian, N. Rastkari, M. Salari, Mesoporous metal organic frameworks functionalized with the amino acids as advanced sorbents for the removal of bacterial endotoxins from water: Optimization, regression and kinetic models, Journal of Molecular Liquids, 339 (2021) 116801.

[27] M. Babapour, M. Hadi Dehghani, M. Alimohammadi, M. Moghadam Arjmand, M. Salari, L. Rasuli, N.M. Mubarak, N. Ahmad Khan, Adsorption of $\mathrm{Cr}(\mathrm{VI})$ from aqueous solution using mesoporous metal-organic framework-5 functionalized with the amino acids: Characterization, optimization, linear and nonlinear kinetic models, Journal of Molecular Liquids, 345 (2022) 117835.

[28] Q. Yang, S. Vaesen, M. Vishnuvarthan, F. Ragon, C. Serre, A. Vimont, M. Daturi, G. De Weireld, G. Maurin, Probing the adsorption performance of the hybrid porous MIL-68 (Al): a synergic combination of experimental and modelling tools, Journal of Materials Chemistry, 22 (2012) 1021010220.

[29] M.R. Samarghandi, A. Dargahi, A. Rahmani, A. Shabanloo, A. Ansari, D. Nematollahi, Application of a fluidized three-dimensional electrochemical reactor with $\mathrm{Ti} / \mathrm{SnO} 2-\mathrm{Sb} / \beta-\mathrm{PbO} 2$ anode and granular activated carbon particles for degradation and mineralization of 2,4-dichlorophenol: Process optimization and degradation pathway, Chemosphere, 279 (2021) 130640.

[30] A. Rahmani, M. Leili, A. Seid-mohammadi, A. Shabanloo, A. Ansari, D. Nematollahi, S. Alizadeh, Improved degradation of diuron herbicide and pesticide wastewater treatment in a three-dimensional electrochemical reactor equipped with $\mathrm{PbO} 2$ anodes and granular activated carbon particle electrodes, Journal of Cleaner Production, 322 (2021) 129094.

[31] Z.-Q. Li, J.-C. Yang, K.-W. Sui, N. Yin, Facile synthesis of metal-organic framework MOF-808 for arsenic removal, Materials Letters, 160 (2015) 412-414.

[32] Z. Wu, X. Yuan, H. Zhong, H. Wang, L. Jiang, G. Zeng, H. Wang, Z. Liu, Y. Li, Highly efficient adsorption of Congo red in single and binary water with cationic dyes by reduced graphene oxide decorated NH2-MIL-68(Al), Journal of Molecular Liquids, 247 (2017) 215-229.

[33] B. Seoane, V. Sebastián, C. Téllez, J. Coronas, Crystallization in THF: the possibility of one-pot synthesis of mixed matrix membranes containing MOF MIL-68 (Al), CrystEngComm, 15 (2013) 94839490.

[34] M.S. Tehrani, R. Zare-Dorabei, Competitive removal of hazardous dyes from aqueous solution by MIL-68(Al): Derivative spectrophotometric method and response surface methodology approach, Spectrochimica Acta Part A: Molecular and Biomolecular Spectroscopy, 160 (2016) 8-18. 
[35] Y. Jiang, B. Zhang, J. Li, Y. Sun, X. Wang, P. Ma, D. Song, One-step fabrication of hydrophilic MIL-68(Al)/Chitosan-coated melamine sponge for vortex-assisted solid-phase extraction of parabens in water samples, Talanta, 224 (2021) 121799.

[36] F. Mahmoudi, M.M. Amini, Confined crystallization of microporous metal-organic framework within mesoporous silica with enhanced hydrostability: Ultrafast removal of organic dyes from aqueous solutions by MIL-68(Al)@SBA-15 composite, Journal of Water Process Engineering, 35 (2020) 101227.

[37] K.-Y.A. Lin, Y.-T. Liu, S.-Y. Chen, Adsorption of fluoride to UiO-66-NH2 in water: stability, kinetic, isotherm and thermodynamic studies, Journal of colloid and interface science, 461 (2016) 7987.

[38] J.-W. Liu, Y. Zhang, X.-W. Chen, J.-H. Wang, Graphene oxide-rare earth metal-organic framework composites for the selective isolation of hemoglobin, ACS applied materials \& interfaces, 6 (2014) 10196-10204.

[39] S. Hou, Y.-n. Wu, L. Feng, W. Chen, Y. Wang, C. Morlay, F. Li, Green synthesis and evaluation of an iron-based metal-organic framework MIL-88B for efficient decontamination of arsenate from water, Dalton transactions, 47 (2018) 2222-2231.

[40] D. Xie, Y. Ma, Y. Gu, H. Zhou, H. Zhang, G. Wang, Y. Zhang, H. Zhao, Bifunctional NH 2-MIL88 (Fe) metal-organic framework nanooctahedra for highly sensitive detection and efficient removal of arsenate in aqueous media, Journal of Materials Chemistry A, 5 (2017) 23794-23804.

[41] Y. Lv, R. Zhang, S. Zeng, K. Liu, S. Huang, Y. Liu, P. Xu, C. Lin, Y. Cheng, M. Liu, Removal of p-arsanilic acid by an amino-functionalized indium-based metal-organic framework: Adsorption behavior and synergetic mechanism, Chemical Engineering Journal, 339 (2018) 359-368.

[42] A. Rahmani, M. Salari, K. Tari, A. Shabanloo, N. Shabanloo, S. Bajalan, Enhanced degradation of furfural by heat-activated persulfate/nZVI-rGO oxidation system: Degradation pathway and improving the biodegradability of oil refinery wastewater, Journal of Environmental Chemical Engineering, 8 (2020) 104468.

[43] A.R. Rahmani, A. Shabanloo, M. Fazlzadeh, Y. Poureshgh, M. Vanaeitabar, Optimization of sonochemical decomposition of ciprofloxacin antibiotic in US/PS/nZVI process by CCD-RSM method, Desalination and Water Treatment, 145 (2019) 300-308.

[44] R. Shokoohi, A. Rahmani, D. Nematollahi, N. Shabanloo, Enhancement of biological sludge dewaterability by a bipolar electro-dewatering system: process modeling and optimization using CCDgenetic algorithm method, Biomass Conversion and Biorefinery, (2021).

[45] Z. Liu, J. Chen, Y. Wu, Y. Li, J. Zhao, P. Na, Synthesis of magnetic orderly mesoporous $\alpha-\mathrm{Fe} 2 \mathrm{O} 3$ nanocluster derived from MIL-100(Fe) for rapid and efficient arsenic(III,V) removal, Journal of Hazardous Materials, 343 (2018) 304-314.

[46] E.-K. Jeon, S. Ryu, S.-W. Park, L. Wang, D.C.W. Tsang, K. Baek, Enhanced adsorption of arsenic onto alum sludge modified by calcination, Journal of Cleaner Production, 176 (2018) 54-62. 
[47] J. Sun, X. Zhang, A. Zhang, C. Liao, Preparation of Fe-Co based MOF-74 and its effective adsorption of arsenic from aqueous solution, Journal of Environmental Sciences, 80 (2019) 197-207. [48] T.A. Vu, G.H. Le, C.D. Dao, L.Q. Dang, K.T. Nguyen, Q.K. Nguyen, P.T. Dang, H.T. Tran, Q.T. Duong, T.V. Nguyen, Arsenic removal from aqueous solutions by adsorption using novel MIL-53 (Fe) as a highly efficient adsorbent, Rsc Advances, 5 (2015) 5261-5268.

[49] H. Wu, M.-D. Ma, W.-Z. Gai, H. Yang, J.-G. Zhou, Z. Cheng, P. Xu, Z.-Y. Deng, Arsenic removal from water by metal-organic framework MIL-88A microrods, Environmental science and pollution research, 25 (2018) 27196-27202.

[50] A. Shukla, Y.-H. Zhang, P. Dubey, J.L. Margrave, S.S. Shukla, The role of sawdust in the removal of unwanted materials from water, Journal of Hazardous Materials, 95 (2002) 137-152.

[51] X. Hu, J. Wen, H. Zhang, Q. Wang, C. Yan, L. Xing, Can epicatechin gallate increase Cr (VI) adsorption and reduction on ZIF-8?, Chemical Engineering Journal, 391 (2020) 123501.

[52] S.S.K. Jampa, A.P. Unnarkat, R. Vanshpati, S. Pandian, M.K. Sinha, S. Dharaskar, Adsorption and recyclability aspects of humic acid using nano-ZIF-8 adsorbent, Environmental Technology \& Innovation, 19 (2020) 100927.

[53] F. Xie, Z. Dai, Y. Zhu, G. Li, H. Li, Z. He, S. Geng, F. Wu, Adsorption of phosphate by sediments in a eutrophic lake: Isotherms, kinetics, thermodynamics and the influence of dissolved organic matter, Colloids and Surfaces A: Physicochemical and Engineering Aspects, 562 (2019) 16-25.

[54] E. Eren, Removal of basic dye by modified Unye bentonite, Turkey, Journal of hazardous materials, 162 (2009) 1355-1363.

[55] X. He, F. Deng, T. Shen, L. Yang, D. Chen, J. Luo, X. Luo, X. Min, F. Wang, Exceptional adsorption of arsenic by zirconium metal-organic frameworks: Engineering exploration and mechanism insight, Journal of Colloid and Interface Science, 539 (2019) 223-234.

[56] D. Setyono, S. Valiyaveettil, Chemically modified sawdust as renewable adsorbent for arsenic removal from water, ACS Sustainable Chemistry \& Engineering, 2 (2014) 2722-2729.

[57] N. Zhu, T. Yan, J. Qiao, H. Cao, Adsorption of arsenic, phosphorus and chromium by bismuth impregnated biochar: Adsorption mechanism and depleted adsorbent utilization, Chemosphere, 164 (2016) 32-40.

[58] C.A. Martinson, K. Reddy, Adsorption of arsenic (III) and arsenic (V) by cupric oxide nanoparticles, Journal of colloid and interface science, 336 (2009) 406-411.

[59] X. Luo, C. Wang, S. Luo, R. Dong, X. Tu, G. Zeng, Adsorption of As (III) and As (V) from water using magnetite $\mathrm{Fe} 3 \mathrm{O} 4-$ reduced graphite oxide- $\mathrm{MnO} 2$ nanocomposites, Chemical Engineering Journal, 187 (2012) 45-52.

[60] J. Cai, X. Wang, Y. Zhou, L. Jiang, C. Wang, Selective adsorption of arsenate and the reversible structure transformation of the mesoporous metal-organic framework MIL-100 (Fe), Physical chemistry chemical physics, 18 (2016) 10864-10867. 
[61] B.-J. Zhu, X.-Y. Yu, Y. Jia, F.-M. Peng, B. Sun, M.-Y. Zhang, T. Luo, J.-H. Liu, X.-J. Huang, Iron and 1, 3, 5-benzenetricarboxylic metal-organic coordination polymers prepared by solvothermal method and their application in efficient As (V) removal from aqueous solutions, The Journal of Physical Chemistry C, 116 (2012) 8601-8607.

[62] K. Folens, K. Leus, N.R. Nicomel, M. Meledina, S. Turner, G. Van Tendeloo, G.D. Laing, P. Van Der Voort, Fe3O4@ MIL-101-A Selective and Regenerable Adsorbent for the Removal of As Species from Water, European Journal of Inorganic Chemistry, 2016 (2016) 4395-4401.

[63] Y.-n. Wu, M. Zhou, B. Zhang, B. Wu, J. Li, J. Qiao, X. Guan, F. Li, Amino acid assisted templating synthesis of hierarchical zeolitic imidazolate framework-8 for efficient arsenate removal, Nanoscale, 6 (2014) 1105-1112.

[64] C. Zhang, Y. Xiao, Y. Qin, Q. Sun, S. Zhang, A novel highly efficient adsorbent \{[Co4 (L) 2 ( $\mu 3-$ $\mathrm{OH}) 2$ (H2O) 3 (4, 4'-bipy) 2].(H2O) 2\} n: Synthesis, crystal structure, magnetic and arsenic (V) absorption capacity, Journal of Solid State Chemistry, 261 (2018) 22-30.

[65] J.-B. Huo, L. Xu, X. Chen, Y. Zhang, J.-C.E. Yang, B. Yuan, M.-L. Fu, Direct epitaxial synthesis of magnetic Fe3O4@ UiO-66 composite for efficient removal of arsenate from water, Microporous and Mesoporous Materials, 276 (2019) 68-75.

[66] C.O. Audu, H.G.T. Nguyen, C.-Y. Chang, M.J. Katz, L. Mao, O.K. Farha, J.T. Hupp, S.T. Nguyen, The dual capture of As V and As III by UiO-66 and analogues, Chemical science, 7 (2016) 6492-6498. [67] M. Ghanbarian, R. Nabizadeh, S. Nasseri, F. Shemirani, A.H. Mahvi, M.H. Beyki, A. Mesdaghinia, Potential of amino-riched nano-structured MnFe2O4@ cellulose for biosorption of toxic Cr (VI): modeling, kinetic, equilibrium and comparing studies, International journal of biological macromolecules, 104 (2017) 465-480.

[68] Y.-S. Ho, A.E. Ofomaja, Pseudo-second-order model for lead ion sorption from aqueous solutions onto palm kernel fiber, Journal of hazardous materials, 129 (2006) 137-142.

[69] W. Weber, J. Morris, Intraparticle diffusion during the sorption of surfactants onto activated carbon, J. Sanit. Eng. Div. Am. Soc. Civ. Eng, 89 (1963) 53-61.

[70] Y. Gu, D. Xie, Y. Wang, W. Qin, H. Zhang, G. Wang, Y. Zhang, H. Zhao, Facile fabrication of composition-tunable $\mathrm{Fe} / \mathrm{Mg}$ bimetal-organic frameworks for exceptional arsenate removal, Chemical Engineering Journal, 357 (2019) 579-588.

[71] C. Yin, S. Li, L. Liu, Q. Huang, G. Zhu, X. Yang, S. Wang, Structure-tunable trivalent Fe-Albased bimetallic organic frameworks for arsenic removal from contaminated water, Journal of Molecular Liquids, (2021) 117101.

[72] Q. Guo, Y. Li, X.-Y. Wei, L.-W. Zheng, Z.-Q. Li, K.-G. Zhang, C.-G. Yuan, Electrospun metalorganic frameworks hybrid nanofiber membrane for efficient removal of $\mathrm{As}(\mathrm{III})$ and $\mathrm{As}(\mathrm{V})$ from water, Ecotoxicology and Environmental Safety, 228 (2021) 112990.

[73] Y. Bulut, Z. Tez, Adsorption studies on ground shells of hazelnut and almond, Journal of hazardous materials, 149 (2007) 35-41. 
[74] J.-B. Huo, G. Yu, L. Xu, M.-L. Fu, Porous walnut-like La2O2CO3 derived from metal-organic frameworks for arsenate removal: A study of kinetics, isotherms, and mechanism, Chemosphere, 271 (2021) 129528.

[75] B. Nagy, C. Mânzatu, A. Măicăneanu, C. Indolean, L. Barbu-Tudoran, C. Majdik, Linear and nonlinear regression analysis for heavy metals removal using Agaricus bisporus macrofungus, Arabian Journal of Chemistry, 10 (2017) S3569-S3579. 